\title{
Meeting the unmet: from traditional to cutting-edge techniques for poly lactide and poly lactide-co-glycolide microparticle manufacturing
}

\author{
Aurélie Schoubben $^{1}$ (D) Maurizio Ricci ${ }^{1}$. Stefano Giovagnoli ${ }^{1}$ (I)
}

Received: 15 March 2019 / Accepted: 24 April 2019 / Published online: 29 April 2019

(c) The Author(s) 2019, corrected publication 2019

\begin{abstract}
Background Polylactides (PLA) and poly lactide-co-glycolides (PLGA) undoubtedly are among the major drivers in the pharmaceutical market. Their relevance in pharmaceutics and biomedicine is well established in light of their sustainability, safety, tunable biodegradability, and versatility. However, polymer degradability and plasticity can somehow restrain industrial developability of PLA and PLGA formulations, especially in the form of microparticles (MP).

Area covered This review wants to deal with the known manufacturing issues of PLA/PLGA MP, debating the potential contribution of modern and cutting-edge manufacturing technologies to the solution of unmet production needs. Technological and regulatory aspects will be considered outlining the potential role of advanced manufacturing techniques in the advancement of PLA/PLGA MP production processes.

Expert opinion The multifaceted complexity of PLA/PLGA MP manufacturing processes demands adequate standardization and updated guidelines covering the so far unmet industrialization requirements. Novel and evolving manufacturing technologies will surely support the future development of bench-to-production plant transfer for such products. Careful evaluation of production costs is demanded in order to ensure process sustainability and patient's outreach.
\end{abstract}

Keywords Microparticles $\cdot$ PLA $\cdot$ PLGA $\cdot$ Microparticle manufacturing $\cdot$ Advanced manufacturing technology

\section{Introduction}

A comprehensive history outline and a description of basic properties of polylactide (PLA) and polylactide-co-glycolide (PLGA) polymers and microparticle (MP) preparation are broadly available in literature (Lee et al. 2016; Swider et al. 2018) and therefore this review will not go back to the fundamentals on such materials and drug delivery systems but rather it will try to dig into the aspects impacting manufacturing of polyester-based MP and the new advanced technologies sought by industry. A particular emphasis will be given to those aspects enabling progress in the transfer to production scale of novel manufacturing techniques deemed to overcome the known limitations in the use of such polymers and the relative unmet issues.

Stefano Giovagnoli

stefano.giovagnoli@unipg.it

1 Department of Pharmaceutical Sciences, University of Perugia, via del Liceo 1, 06123 Perugia, Italy

\section{Strengths and weaknesses of PLA and PLGA polymers}

PLA and PLGA polymers are shear thinning materials that, depending on their composition and molecular weight, can show different degree of plasticity and degradability. PLA polymers exist as $\mathrm{D}$ and $\mathrm{L}$ isomers according to lactic acid configuration, that leads to different polymer tacticity and therefore material properties (Baker et al. 2008; Shaver and Cameron 2010). As a result, while L-PLA is highly crystalline, D-PLA is completely amorphous. The isomerism of lactides influences also PLGA tacticity and physical state. Albeit mainly amorphous, L-PLGA and DL-PLGA polymers can show a certain degree of crystallinity depending on the lactide/glycolide ratio and stereoisomeric composition of the lactide monomers (Avgoustakis 2015). The knowledge of such properties is therefore important as crystallinity affects the rate of degradation and the mechanical properties of PLA and PLGA. As a consequence, the choice of proper polymers for manufacturing of PLA and PLGA MP should account for the insightful knowledge of these fundamental properties. 
In fact, along with their recognized safety as FDA-approved parenteral materials, the undeniable attractiveness of such polymers in drug delivery is tightly bound to their tunable drug release behavior that grants sustained and extended drug delivery applications. The choice of copolymer composition and/or lactide isomer as well as polymer molecular weight consent to tailor MP degradation and drug release profile (Anderson and Shive 2012). However, this high versatility and workability is actually counterbalanced by polymer plasticity, which determines the PLA and PLGA attitude to undergo softening and unwanted degradation upon manufacturing and storage (Allison 2008). In fact, the tunable biodegradability of these polymers represents at the same time their strength and weakness as it makes them prone to acid- and base-catalyzed degradation. Such degradation has been found to occur even in MP formulations when basic or acidic drugs are being encapsulated (Selmin et al. 2012; D'Souza et al. 2014a, 2015). Naturally, these phenomena affect amorphous materials most. Since PLGA and PLA are generally low glassy polymers, interaction with other materials, such as excipients, solvents, drugs, and temperature can easily provoke plasticization and annealing of the solid matrix. Even though plasticization can be favorable to processing and the manufacturing of scaffolds and other devices, it can be detrimental to MP manufacturing and storage stability and today increased efforts are directed to identify effective stabilization strategies (Albertini et al. 2015; Benvenutti et al. 2018). Therefore, these features can represent a considerable bottleneck in the development of PLA and PLGA MP products. In fact, the susceptibility of these polymers to boundary conditions and the interaction with other materials, drugs included, makes PLA and PLGA MP manufacturing prone to high variability in the absence of a robust control over all process parameters that partially explains the lack of generic products in the market (Zhou et al. 2018). However, novel technologies with enhanced performances and stability, which will be herein discussed, may underpin remarkable advances in the manufacturing of these problematic products.

\section{PLA and PLGA microparticles in the pharmaceutical market}

To date, there are about 20 PLA/PLGA based products approved by the Food and Drug Administration (FDA) and the European Medicines Agency (EMA) mainly aimed to be administered by intramuscular or subcutaneous injection (Table 1) (Silverman et al. 2002; Wang et al. 2016; Tice 2017; Qi et al. 2018; CenterWatch 2019. Other products are to be inserted in the periodontal cavity (e.g., Arestin ${ }^{\circledR}$ ) or by intra-articular injection (i.e., Zilretta ${ }^{\circledR}$ ). The aim of using polyesters in these formulations are several and in particular PLA/PLGA consent to simplify the therapeutic schedule (i.e., reducing the administration frequency), to minimize drug concentration oscillation reducing side effects and to improve patient's adherence to the treatment. The low availability of PLA/PLGA based medicines can be mainly ascribed to the difficulties encountered during their development and industrial manufacturing. However, recently, two new formulations reached the USA market after FDA approval. Zilretta ${ }^{\circledR}$ are triamcinolone acetonide loaded MP for intra-articular injection in the treatment of knee pain in patients with osteoarthritis (Kaufman 2017, 2018a). Triptodur ${ }^{\mathrm{TM}}$, based on the use of triptorelin pamoate, was approved in 2017 for the treatment of central precocious puberty. This formulation is administered only twice yearly by intramuscular injection (2018b). In the European market, a triptorelin based formulation (Salvacyl ${ }^{\circledR}$ LP, Salvapar ${ }^{\circledR}$, Moapar $^{\circledR}$ ) was approved in 12 countries from 2006 to 2014 for the treatment of severe sexual deviation (Debiopharm group; Briken et al. 2012). PLA/PLGA MP based technologies are being exploited for drug repurposing of commercial oral or extended release preparations as witnessed by the large number of completed clinical trials on risperidone based products and the ongoing efforts in several therapeutic areas (Table 2). These considerable research investments in such technologies somehow underpin the advantages of PLA/ PLGA based long acting injectables (LAI) especially for the treatment of chronic pathological conditions. Unfortunately, these advantages are overweighed by the intrinsic complexity of such formulations as well as limited regulatory support. As a consequence, to date, no generic version of these products is available on the market even though patent protection of some of them has expired (e.g., Lupron ${ }^{\circledR}$ Depot). This can be explained by the difficulty in manufacturing PLA/PLGA MP obtaining perfectly reproducible characteristics such as drug loading and drug release profile. In fact, slight modifications of the manufacturing process can deeply affect MP properties and therefore treatment safety. There is also a lack of suitable tools to evaluate the impact of MP features on their performances (D'Souza et al. 2014b, c). That is why the FDA's Office of Generic Drug (OGD) supports research to develop in vitro-in vivo correlations and in vitro release testing methods (Schoubben et al. 2012; Leblanc 2018).

\section{Conventional manufacturing technology}

\section{Lab-scale methods}

\section{Solvent evaporation and extraction}

PLA and PLGA MP are often prepared by organic solvent evaporation/extraction from oil-in-water $(\mathrm{o} / \mathrm{w})$ or water-in-oil-in-water $(\mathrm{w} / \mathrm{o} / \mathrm{w})$ emulsions (Schoubben 
Table 1 FDA and EMA marketed microparticles based on PLA/PLGA (not intended to be fully exhaustive)

\begin{tabular}{|c|c|c|c|c|c|c|}
\hline Brand name & API & $\begin{array}{l}\text { Administration } \\
\text { route }\end{array}$ & Indication(s) & $\begin{array}{l}\text { Encapsulation } \\
\text { technology }\end{array}$ & $\begin{array}{l}\text { Encapsulation } \\
\text { process }\end{array}$ & $\begin{array}{l}\text { Approval/launched } \\
\text { year }\end{array}$ \\
\hline Arestin $^{\circledR}$ & Minocycline $\mathrm{HCl}$ & Periodontal & $\begin{array}{l}\text { Periodontal } \\
\text { disease }\end{array}$ & NA & NA & 2001 \\
\hline Bydureon $^{\circledR}$ & Exenatide & Subcutaneous & Type 2 diabetes & Medisorb $^{\circledR}$ & $\begin{array}{l}\text { Solvent evapora- } \\
\text { tion/extraction } \\
\text { emulsion method }\end{array}$ & 2012 \\
\hline $\begin{array}{l}\text { Decapeptyl }{ }^{\circledR}, \\
\text { Decapeptyl }^{\circledR} \text { SR }\end{array}$ & Triptorelin acetate & Intramuscular & Prostatic cancer & Debio PLGA-2 ${ }^{\circledR}$ & $\begin{array}{l}\text { Oil-in-water emul- } \\
\text { sion method/ } \\
\text { phase separation }\end{array}$ & 1986 \\
\hline $\begin{array}{l}\text { Lupron }^{\circledR} \text { Depot, } \\
\text { Enantone }^{\circledR} \\
\text { Prostap }^{\circledR} \mathrm{SR}\end{array}$ & Leuprolide acetate & Intramuscular & $\begin{array}{l}\text { Endometriosis } \\
\text { Prostatic cancer }\end{array}$ & NA & $\begin{array}{l}\text { Water-in-oil emul- } \\
\text { sion }\end{array}$ & $\begin{array}{l}1999 \\
1989,1996-1997\end{array}$ \\
\hline $\begin{array}{l}\text { Lupron }{ }^{\circledR} \text { Depot- } \\
\text { PED, Enantone }{ }^{\circledR} \text {, } \\
\text { Prostap }{ }^{\circledR} \text { SR }\end{array}$ & Leuprolide acetate & Intramuscular & $\begin{array}{l}\text { Central precocious } \\
\text { puberty }\end{array}$ & NA & $\begin{array}{l}\text { Water-in-oil emul- } \\
\text { sion }\end{array}$ & 2011 \\
\hline $\begin{array}{l}\text { Pamorelin }{ }^{\circledR} \text { LA, } \\
\text { Trelstar }{ }^{\circledR} \text { Depot, } \\
\text { Trelstar }{ }^{\circledR} \text { LA }\end{array}$ & $\begin{array}{l}\text { Triptorelin pamo- } \\
\text { ate/embonate }\end{array}$ & Intramuscular & Prostatic cancer & Debio PLGA-2 ${ }^{\circledR}$ & $\begin{array}{l}\text { Oil-in-water emul- } \\
\text { sion method/ } \\
\text { phase separation }\end{array}$ & 2010, 2000, 2001 \\
\hline Parlodel ${ }^{\circledR}$ LAR & Bromocriptine & Intramuscular & $\begin{array}{l}\text { Prolactin-secreting } \\
\text { tumor }\end{array}$ & NA & Spray-drying & $\sim 1991$ \\
\hline $\begin{array}{l}\text { Risperdal }{ }^{\circledR} \text { Con- } \\
\text { sta }^{\mathrm{TM}}\end{array}$ & Risperidone & Intramuscular & $\begin{array}{l}\text { Schizophrenia, } \\
\text { bipolar I disorder }\end{array}$ & Medisorb $^{\circledR}$ & $\begin{array}{l}\text { Solvent evapora- } \\
\text { tion/extraction } \\
\text { emulsion method }\end{array}$ & 2003 \\
\hline $\begin{array}{c}\text { Salvacyl }{ }^{\circledR}{ }^{\circledR}, \\
\text { Salvapar }^{\circledR}, \\
\text { Moapar }^{\circledR}\end{array}$ & $\begin{array}{l}\text { Triptorelin pamo- } \\
\text { ate/embonate }\end{array}$ & Intramuscular & $\begin{array}{c}\text { Severe sexual } \\
\text { deviation in } \\
\text { adult men }\end{array}$ & Debio PLGA-2 ${ }^{\circledR}$ & $\begin{array}{l}\text { Oil-in-water emul- } \\
\text { sion method/ } \\
\text { phase separation }\end{array}$ & $\begin{array}{l}\text { 2006-2014 (12 } \\
\text { countries in } \\
\text { Europe) }\end{array}$ \\
\hline Sandostatin LAR & Octreotide & Subcutaneous & $\begin{array}{l}\text { Acromegaly, } \\
\text { severe diarrhea } \\
\text { with metastatic } \\
\text { carcinoma or } \\
\text { with vasoac- } \\
\text { tive intestinal } \\
\text { peptide-secreting } \\
\text { tumors }\end{array}$ & Medisorb $^{\circledR}$ & $\begin{array}{l}\text { Solvent evapora- } \\
\text { tion/extraction } \\
\text { emulsion method }\end{array}$ & 1997 \\
\hline Signifor ${ }^{\circledR}$ LAR & $\begin{array}{l}\text { Pasireotide pamo- } \\
\text { ate }\end{array}$ & Intramuscular & $\begin{array}{l}\text { Acromegaly, } \\
\text { Cushing's } \\
\text { disease }\end{array}$ & Novartis & NA & 2014 \\
\hline $\begin{array}{l}\text { Somatuline }{ }^{\circledR} \\
\text { Depot }\end{array}$ & Lanreotide & Intramuscular & Acromegaly & NA & NA & 2007 \\
\hline Suprecur ${ }^{\circledR}$ MP & Buserelin acetate & & Endometriosis & NA & Spray-drying & 2002 \\
\hline Triptodur ${ }^{\mathrm{TM}}$ & $\begin{array}{l}\text { Triptorelin pamo- } \\
\text { ate/embonate }\end{array}$ & Intramuscular & $\begin{array}{l}\text { Central precocious } \\
\text { puberty }\end{array}$ & Debio PLGA-2 ${ }^{\circledR}$ & $\begin{array}{l}\text { Oil-in-water emul- } \\
\text { sion method/ } \\
\text { phase separation }\end{array}$ & 2017 \\
\hline Vivitrol $^{\circledR}$ & Naltrexone & Intramuscular & $\begin{array}{l}\text { Alcohol depend- } \\
\text { ence } \\
\text { Opioid depend- } \\
\text { ence }\end{array}$ & Medisorb $^{\circledR}$ & $\begin{array}{l}\text { Solvent evapora- } \\
\text { tion/extraction } \\
\text { emulsion method }\end{array}$ & 2010 \\
\hline Zilretta $^{\circledR}$ & $\begin{array}{l}\text { Triamcinolone } \\
\text { acetonide }\end{array}$ & Intra-articular & $\begin{array}{l}\text { Osteoarthritis knee } \\
\text { pain }\end{array}$ & NA & NA & 2017 \\
\hline
\end{tabular}

et al. 2009; Albertini et al. 2015; Casagrande et al. 2017). This technique has been developed at the end of the 1970s (Hu et al. 2017). Based on the nature of the active pharmaceutical ingredient (API), one can choose to use o/w or w/o/w emulsions (Jain 2000; Rosca et al.
2004; Lu and Park 2012; Kapoor et al. 2015; Lee et al. 2016; Swider et al. 2018). Commonly, o/w emulsion is used with hydrophobic API (Ricci et al. 2005; Giovagnoli et al. 2010), while w/o/w emulsion is preferred for hydrophilic API such as peptide and proteins to maximize drug 
Table 2 PLA/PLGA MP based depot products under clinical investigation (not intended to be fully exhaustive)

\begin{tabular}{|c|c|c|c|c|c|c|}
\hline Brand name & API & Route* & Indication(s) & Encapsulation technology & Description & Stage \\
\hline Bydureon $^{\circledR}$ & Exenatide & $\mathrm{SC}$ & Type 2 diabetes & Medisorb $^{\circledR}$ & $\begin{array}{l}\text { Effect of Bydureon on } \\
\text { carotid atherosclerosis } \\
\text { progression in T2DM }\end{array}$ & Phase 4 \\
\hline Copaxone ${ }^{\circledR}$ Depot & Glatiramer acetate & $\mathrm{IM}$ & $\begin{array}{l}\text { Primary progressive multi- } \\
\text { ple sclerosis }\end{array}$ & MAPI-pharma & $\begin{array}{l}\text { A prospective, multicenter, } \\
\text { single arm, open label, } \\
\text { Phase IIa study to assess } \\
\text { the safety and efficacy of } \\
\text { once-a-month long-acting } \\
\text { intramuscular injection of } \\
40 \mathrm{mg} \text { glatiramer acetate } \\
\text { (GA depot) in subjects } \\
\text { with primary progres- } \\
\text { sive multiple sclerosis } \\
\text { (PPMS) }\end{array}$ & Phase 2 \\
\hline Copaxone $^{\circledR}$ Depot & Glatiramer acetate & $\mathrm{IM}$ & Multiple sclerosis & MAPI-pharma & $\begin{array}{l}\text { A prospective 1-year, } \\
\text { open-label, two arms, } \\
\text { multicenter, Phase IIa } \\
\text { study to assess safety, tol- } \\
\text { erability and efficacy of } \\
\text { once a month long-acting } \\
\text { intramuscular injection } \\
\text { of } 80 \text { or } 40 \text { mg glatiramer } \\
\text { acetate (GA depot) in } \\
\text { subjects with relaps- } \\
\text { ing-remitting multiple } \\
\text { sclerosis (RRMS) }\end{array}$ & $\begin{array}{l}\text { Phase } 1 \\
\text { Phase } 2\end{array}$ \\
\hline Sandostatin ${ }^{\circledR}$ LAR & Octreotide & $\mathrm{SC}$ & $\begin{array}{l}\text { Hereditary hemorrhagic } \\
\text { telangiectasia } \\
\text { Gastrointestinal hemor- } \\
\text { rhage } \\
\text { Anemia }\end{array}$ & Medisorb $^{\circledR}$ & $\begin{array}{l}\text { An uncontrolled, pilot- } \\
\text { study assessing the effi- } \\
\text { cacy of octreotide long- } \\
\text { acting release to decrease } \\
\text { transfusion requirements } \\
\text { and endoscopy frequency } \\
\text { in patients with rendu- } \\
\text { osler-weber and gastroin- } \\
\text { testinal bleeding }\end{array}$ & Phase 2 \\
\hline Sandostatin ${ }^{\circledR}$ LAR & Octreotide & $\mathrm{SC}$ & $\begin{array}{l}\text { Angiodysplasia } \\
\text { vascular Malformations } \\
\text { Gastrointestinal hemor- } \\
\text { rhage } \\
\text { anemia }\end{array}$ & Medisorb $^{\circledR}$ & $\begin{array}{l}\text { A multicenter, randomized, } \\
\text { open-label clinical trial } \\
\text { assessing the efficacy of } \\
\text { octreotide in decreasing } \\
\text { blood and iron require- } \\
\text { ments in patients with } \\
\text { refractory anaemia due to } \\
\text { angiodysplasias }\end{array}$ & $\begin{array}{l}\text { Phase } 2 \\
\text { Phase } 3\end{array}$ \\
\hline Signifor ${ }^{\circledR}$ LAR & Pasireotide & IM & $\begin{array}{l}\text { Neuroendocrine tumors } \\
\text { Carcinoid Tumors }\end{array}$ & Novartis & $\begin{array}{l}\text { Phase II study of Pasire- } \\
\text { otide LAR in patients } \\
\text { with metastatic neuroen- } \\
\text { docrine carcinomas }\end{array}$ & Phase 2 \\
\hline Signifor ${ }^{\circledR}$ LAR & Pasireotide & IM & $\begin{array}{l}\text { ACTH-producing pituitary } \\
\text { tumour }\end{array}$ & Novartis & $\begin{array}{l}\text { Pilot study of Pasireotide } \\
\text { LAR treatment of silent } \\
\text { corticotrophin pituitary } \\
\text { tumors and effects on } \\
\text { plasma levels of POMC }\end{array}$ & Phase 2 \\
\hline Vivitrol $^{\circledR}$ & Naltrexone & IM & Opiate addiction & Medisorb $^{\circledR}$ & $\begin{array}{l}\text { Long-acting naltrexone } \\
\text { for pre-release prison- } \\
\text { ers: a randomized trial of } \\
\text { mobile treatment }\end{array}$ & Phase 3 \\
\hline Vivitrol $^{\circledR}$ & Naltrexone & IM & Opioid use disorders & Medisorb $^{\circledR}$ & $\begin{array}{l}\text { Depot pharmacotherapies } \\
\text { for opioid-dependent } \\
\text { offenders: outcomes and } \\
\text { costs }\end{array}$ & Phase 3 \\
\hline
\end{tabular}


Table 2 (continued)

\begin{tabular}{|c|c|c|c|c|c|c|}
\hline Brand name & API & Route* & Indication(s) & Encapsulation technology & Description & Stage \\
\hline Vivitrol $^{\circledR}$ & Naltrexone & IM & Opioid use disorders & Medisorb $^{\circledR}$ & $\begin{array}{l}\text { Long acting naltrexone } \\
\text { for opioid addiction: the } \\
\text { importance of mental, } \\
\text { physical and societal } \\
\text { factors for sustained } \\
\text { abstinence and recovery }\end{array}$ & Phase 4 \\
\hline Vivitrol $^{\circledR}$ & Naltrexone & IM & Opioid use disorders & Medisorb $^{\circledR}$ & $\begin{array}{l}\text { A feasibility study for } \\
\text { testing the effects } \\
\text { of extended-release } \\
\text { naltrexone (Vivitrol) } \\
\text { on recidivism and other } \\
\text { participant outcomes in } \\
\text { drug court settings }\end{array}$ & Phase 4 \\
\hline Vivitrol $^{\circledR}$ & Naltrexone & IM & Opioid use disorders & Medisorb $^{\circledR}$ & $\begin{array}{l}\text { A strategy to improve } \\
\text { success of treatment dis- } \\
\text { continuation in buprenor- } \\
\text { phine responders }\end{array}$ & Phase 3 \\
\hline
\end{tabular}

*SC subcutaneous, IM intramuscular

loading (Giovagnoli et al. 2004, 2005, 2010). In fact, it can be difficult to obtain high hydrophilic drug payload in PLA/PLGA MP. Briefly, polymer is solubilized in an organic solvent such as methylene chloride together with the hydrophobic API and emulsified under stirring or sonication in the aqueous phase containing the stabilizing agent (e.g., polyvinyl alcohol, PVA; hydroxypropylmethylcellulose, HPMC). Successively, MP hardening is achieved by evaporating the solvent under reduced pressure and increasing the temperature. In alternative, the organic solvent can be extracted by pouring the emulsion in a large volume of aqueous phase to favor the organic solvent diffusion in the continuous phase (Capan et al. 2003; D'Souza et al. 2013). Hydrophilic API are either solubilized in a minimum volume of water that is the inner aqueous phase of the w/o/w double emulsion (Giovagnoli et al. 2007) or directly suspended in the organic phase obtaining a solid-in-oil-in-water $(\mathrm{s} / \mathrm{o} / \mathrm{w})$ emulsion (Giovagnoli et al. 2008). MP characteristics (i.e., dimensions, porosity, API content, release kinetics, degradation kinetics) depends on the polymer used and on preparation parameters such as the starting polymer concentration, $\mathrm{o} / \mathrm{w}$ volume ratio, stabilizer nature and concentration, agitation conditions, and solvent evaporation rate ( $\mathrm{Lu}$ and Park 2012). As evidenced in Table 1, the MP products existing in the market are essentially prepared using the emulsion technology. However, it is not clear how emulsion is obtained and therefore if this lab-scale method or the membrane emulsification technology described further on is employed.

\section{Cryogenic solvent extraction}

This technique has been developed to limit the exposure of sensitive peptides and/or proteins to the harsh conditions of the solvent evaporation/extraction method. In fact, protein exposure to the w/o interface and temperature used to evaporate the organic solvent can provoke denaturation (van de Weert et al. 2000; Bilati et al. 2005). Cryogenic solvent extraction consists in the nebulization of the suspension made of the protein in dichloromethane where PLA or PLGA has been solubilized above a beaker containing ethanol (Tracy 1998; Yeo et al. 2001). In particular, ethanol has been cooled using liquid nitrogen at a temperature lower that the freezing point of the suspension nebulized. The droplet will freeze coming in contact with the layer of liquid nitrogen present above the frozen ethanol and fall into ethanol bath. Successively, ethanol will be slightly warmed up thawing out dichloromethane that will diffuse in ethanol. As a result, MP will solidify encapsulating the protein. This strategy, namely ProLease ${ }^{\circledR}$ technology, has been applied in different marketed and non-marketed products (Johnson et al. 1997; Tracy 1998; Yaszemski et al. 2003).

\section{Catalytic hydrolysis solvent removal}

Besides dichloromethane, which is the solvent mainly used in the methods illustrated so far, ethyl acetate is an alternative. Its elimination from the o/w emulsion to achieve particle formation is obtained by catalytic hydrolysis in a $\mathrm{HCl}$ aqueous phase at about $30^{\circ} \mathrm{C}$. With respect to the 
conventional extraction procedure, acidic hydrolysis of ethyl acetate granted a higher ketoprofen encapsulation efficiency (Lee et al. 2013). This process can have significative relevance with acidic API, since an acidic aqueous phase will limit their diffusion and loss in the continuous phase. Other papers used isopropyl formate (Im and Sah 2009) or methyl chloroacetate (Kim et al. 2007) as organic phase and their removal was carried out using ammonia solution that provoked solvent hydrolysis obtaining water-miscible formamide and isopropyl alcohol or chloroacetamide and methanol, respectively. As a result, the polymer precipitated encapsulating progesterone, used as a model API, with an encapsulation efficiency in the 64-97\% range (Kim et al. 2007; Im and Sah 2009).

\section{Coacervation}

Coacervation is another technique used to produce PLA/ PLGA MP. It is based on phase separation of the polymer (the coacervate) that coats the API particles. This process is commonly divided in three separate steps:

- Phase separation of the polymer that forms coacervate globules

- Adsorption of the coating polymer droplets on the API particle surface

- Solidification of the polymer around the API particles

In accordance with the triggering element that induces phase separation, different coacervation process can be individuated (i.e., non-solvent addition, temperature change, incompatible polymer addition, salting out, polymer-polymer interaction). However, in the case of PLA and PLGA, not all the different phase separation inducing events are applicable (Jain 2000; Yeo et al. 2001; Ye et al. 2010; Kapoor et al. 2015; Hu et al. 2017).

\section{Non-solvent addition}

Phase separation provoked by non-solvent addition is mainly employed to load water-soluble API but can also be used to encapsulate liposoluble API. Several parameters, such as polymer concentration and stirring rate, influence particle characteristics and non-solvent addition has to be slow to obtain a uniform polymer coating around the API particles (Jain 2000; Ding and Zhu 2018). The non-solvent must be selected to avoid API solubilization and it has to be miscible in the solvent used to solubilize the polymer. Examples of non-solvents that cause phase separation are silicone oil, vegetable oil, low molecular weight methacrylic polymers, which are called first non-solvents. Second non-solvents, used to solidify the polymer layer, can be hexane or petroleum ether (Thomasin et al. 1998; Yeo et al. 2001).

\section{Salt addition}

Salt addition is another strategy used to obtain phase separation of PLA/PLGA solubilized in a water miscible solvent, such as acetone or acetonitrile, together with the lipophilic API. This solution is then emulsified in water containing both the salting-out agent (e.g., calcium chloride, sucrose) and a stabilizer and is then diluted with an excess volume of water promoting acetone diffusion and particle solidification. This technique can be easily scale-up but its application is limited to lipophilic API and requires many washing cycles to remove the salting-out agent (Nagavarma et al. 2012; Lee et al. 2016; Swider et al. 2018). The optimization of the different conditions (e.g., salting out compound nature and concentration, solvent nature, polymer concentration) is essential to obtain MP and not nanoparticles (Wischke and Schwendeman 2008).

\section{Current industrial methods}

\section{Spray-drying}

The spray-drying (SD) technology has evolved over time to meet industry requirements in several production fields. In drug delivery, novel principles and methodologies in droplet formation and drying have enabled considerable expansion of SD applications, including biologicals and enteric formulations (Puccetti et al. 2018; Ziaee et al. 2019). This technique combines a relatively user-friendly setup with versatility and scalability, and ensures a completely closed environment, preventing the risk of room and personnel contamination. Granting fast one-step fabrication and simultaneous control on particle size and morphology, SD is particularly suitable to process susceptible materials and for the manufacturing of precisely tailored dry MP formulations, with the logical benefit of storage stability. According to the nozzle and drying chamber geometries, and recovery method, pulmonary powders, pellets as well as sustained release MP can be fabricated. Since SD can be run in a nearly continuous manner, it can produce large batch sizes with high reproducibility, granting low levels of residual solvent in a closed loop configuration. Nowadays, beside the classical equipment several configurations have been designed with different manufacturing purposes.

The unmatched appeal of SD as a one-step, scalable manufacturing technique has promoted a great deal of research in several fields and, it has been found particularly suitable for PLA and PLGA MP preparation (Sosnik and Seremeta 2015). Exploiting the well-known SD capabilities, a number of works have investigated PLA and PLGA inhalable MP for tuberculosis and other infectious diseases in the attempt to extend the action of pulmonary treatment (Schoubben et al. 2010; Ungaro et al. 2012; Palazzo et al. 2013; Giovagnoli 
et al. 2014; Ibrahim et al. 2018; O'Connor et al. 2019). Additional applications have encompassed other antibiotics, antitumoral, antioxidants and antiinflammatory drugs (Wagenaar and Müller 1994; Mu and Feng 2001; Gavini et al. 2004; Rivera et al. 2004; Youan 2004; Sastre et al. 2007). Unfortunately, to date, none of them has reached the clinical stage.

For an in-depth analysis of the related issues and progresses in the field, interested readers can refer to Liang et al. (Liang et al. 2015), Miranda et al. (Miranda et al. 2018), Das et al. (Das et al. 2015), and Hickey et al. (Hickey et al. 2016).

Beyond its traditional role of controlled drying process and prominence in the inhalable powders area, current SD technologies may reshape manufacturing of injectable sustained release depots as well, as an alternative to emulsion-freeze-drying technologies (Mundargi et al. 2011; Guo et al. 2015; Wan and Yang 2016). In particular, SD is slowly emerging as a manufacturing process of controlled delivery systems for biomolecules and vaccines (Mueller et al. 2012; Allahyari and Mohit 2016; Kanojia et al. 2017). However, in order to climb over the ridge of compliance and controlled release requirements, traditional pitfalls have to be overcome. Among all, initial burst release and heat shock damage restrain most protein loaded spray-dried MP development (Yamaguchi et al. 2002; Mao et al. 2007). Such problems stem from the fast and turbulent drying process that results in poor control over molecular diffusion in the droplet. As a consequence, proteins are released fast from spray-dried MP due to the small particle size and the tendency to migrate at the liquid-air interface.

Nonetheless, novel atomization technologies, based on coaxial ultrasonic, electrospray, and three-fluid pneumatic actuation (Kondo et al. 2014; Wan et al. 2014), will likely prompt the progress towards the production of monodispersed particles with a core-shell structure providing higher drug payloads (Han et al. 2016) and more accurate control on the release behavior. Such innovations have boosted the research in the last years and, likely, in the near future SD is about to become one of the main technologies in the manufacturing of controlled delivery systems for biopharmaceuticals.

Albeit established in some areas of pharmaceutical manufacturing, scale up of SD methods is not straightforward as a result of the intimate liaison between process conditions and product powder properties. Direct scaling of key parameters seems not to be effective due to practical limitations and temporal differences in physical processes, e.g. at pilot and production scales the particle residence time is much higher than at lab scale and yield may vary due to a different adhesion extent to the equipment walls. Complete understanding of scale-dependent and scale-independent factors is therefore strategic along with the design and engineering of a pilot model accounting for critical geometrical and workout requirements (Al-Khattawi et al. 2018). This is one of the reasons for the as yet limited spray-dried depot products on the market.

\section{Supercritical fluids}

The properties of supercritical fluids (SCF) have been exploited in many different areas of pharmaceutics and biomedicine. Several organic solvents and almost all gases above their critical pressure and temperature assume peculiar properties that stem their capacity to act at the same time as a liquid and a gas. The consequence is that such SCF show the solubilization capacity of a solvent along with high diffusivity and low viscosity. The liquid-like properties enable application in extraction processes, solubilization of substances, and matrix plasticization, while gas-like features enhance mass transfer and reaction selectivity. Carbon dioxide is preferred over other SCF due to mild supercritical conditions, low cost and environmental impact.

SCF technologies are today well-established industrial processes that can be applied to manufacturing of fine powders and polymeric micro- and nanocarriers each with advantages and disadvantages (Table 3). In general, the process consists in the formation of solutions or dispersions by exploiting the SCF solvent or anti-solvent capacity and the subsequent coacervation induced by its fast removal through a rapid drop below supercritical conditions. This leads to solvent extraction with subsequent fast solidification of dissolved materials or drying of dispersed particles. SCF can be used as solvents or anti-solvents and solutes and over the years several different processes have been developed according to purposes (Table 3) for an in-depth description of which readers may refer to Kankala et al. (2017), Girotra et al. (2013), Tabernero et al. (2012), and Soh and Lee (2019).

The arsenal of techniques today available is the result of about three decades of continuous research efforts that have led to considerable advances in the methods for the fabrication of tailored drug delivery systems destined to virtually all administration routes. Among all, PLA and PLGA delivery systems have benefited from the increased versatility of RESS and SAS techniques either for MP or nanoparticle formulations. Refinement in the control over coacervation and hardening/drying processes has granted successful development of PLA and PLGA MP for oral, pulmonary and parenteral administration. Antiinflammatory drugs have been microencapsulated in homogeneous injectable PLGA and PLA MP using RESS, SEDS, SAILA, and SFEE processes (Kim et al. 1996; Ghaderi et al. 2000; Chattopadhyay et al. 2006; Kang et al. 2008a; Kluge et al. 2009b; Della Porta et al. 2010; Campardelli et al. 2016; Campardelli and Reverchon 2017). Other examples include morphine, 
Table 3 Classification of SCF processes employed in microparticle and nanoparticle fabrication

\begin{tabular}{lll}
\hline SCF role & Process & \\
\hline Solvent (RESS) & Rapid expansion of supercritical solutions & RESS \\
Solute & Particle from gas saturated solution & PGSS \\
Anti-solvent (SAS) & Solution enhanced dispersion by supercritical process & SEDS \\
& Supercritical fluid extraction of emulsion & SFEE \\
& Supercritical-assisted atomization & SAA \\
& Aerosol solvent extraction system & ASES \\
& Expanded liquid anti-solvent & ELS \\
& Precipitation with compressed anti-solvent & PCA \\
& Suspension-enhanced dispersion by supercritical fluids & SpEDS \\
& Supercritical anti-solvent with enhanced mass transfer & SAS-EM \\
& Gaseous anti-solvent & GAS \\
& Supercritical assisted injection in a liquid anti-solvent & SAILA \\
& Supercritical solvent impregnation & SSI \\
& Depressurization of an expanded liquid organic solution & DELOS \\
& CO -assisted nebulization with a bubble dryer & CAN-BD \\
SCF-assisted spray-drying & SASD \\
& SCF-expansion depressurization & SFED \\
& SCF-processing & SCP \\
\hline
\end{tabular}

methotrexate, and paclitaxel (Kang et al. 2008b; Chen et al. 2012c, 2013b; Huang et al. 2015).

SAS methods have been developed to entrap water-soluble compounds in PLA and PLGA MP. One strategy was to increase solubility in organic solvents by hydrophobic ion pairing, as in the case of gentamycin, nalozoxone, naltrexone (Falk et al. 1997) or addition of co-solvents, as in the case of morphine, bupivacaine, and ketamine (Lee et al. 2006; Zhang et al. 2012; Han et al. 2018).

The possibility to finely control working temperatures and boundary conditions makes SCF-based methods suitable for processing labile materials (Adami et al. 2011). Therefore, microencapsulation of proteins and peptides, such as bovine serum albumin, lysozyme and lipase (Young et al. 1999; Mishima et al. 2000; Tu et al. 2002; Kluge et al. 2009a; Chen et al. 2012b; Tran et al. 2013), insulin (Elvassore et al. 2001; Della Porta et al. 2013), and monoclonal antibodies (Yandrapu et al. 2013), as well as vaccines (Baxendale et al. 2011; Tavares et al. 2017) has been achieved.

The SCF technology enables the rapid and effective assembling of complex composite systems. In this way, nanoparticles can be entrapped within PLGA or PLA MP (Chen et al. 2009b) or can be coated with PLA and PLGA polymers to form core-shell structures (Chen et al. 2009c). This technology can be exploited to produce functional systems, as in the case of magnetic or antibacterial MP (Chen et al. 2009a, 2012a; Campardelli et al. 2013; Cricchio et al. 2017), or composite PLGA/chitosan MP by PGSS (Casettari et al. 2011).

A continuous supercritical emulsion extraction (SEE-C) has been proposed for the production of PLGA MP for the encapsulation of proteins and polypeptides (Della Porta et al. 2011; Campardelli et al. 2012; Falco et al. 2012). SEE-C shows significant improvements compared to batch configuration, as it exploits countercurrent packed columns that enable rapid, continuous extraction of the organic solvents and reproducible formation of PLGA MP with controlled and narrow size distributions. This system demonstrates that SCF technology can be scaled to a high-throughput continuous mode to allow large production yields and batch control.

Naturally, as mentioned above, the highly efficient atomization technologies coupled to SCF can be exploited to produce inhalable powders. Lysozyme, celecoxib, deslorelin, and rifampicin loaded porous PLA and PLGA MP obtained by SAA represent a few examples (Koushik and Kompella 2004; Koushik et al. 2004; Patomchaiviwat et al. 2008; Chen et al. 2013a; Dhanda et al. 2013; Kang et al. 2013). The advantages of SFC in the manufacturing of pulmonary dry powders are a higher control upon the formation of feed dispersion and solutions and a higher efficiency in solvent removal at reduced temperatures. Consequently, the obtained powders show a lower residue of organic solvent, thus a less plasticized solid matrix, and improved particle size distribution and morphology. Moreover, the lower process temperatures enable processing of heat sensitive materials.

\section{Membrane emulsification}

Emulsion solvent extraction/evaporation-based methods still represent one of the major manufacturing processes for PLA and PLGA MP. As discussed above, such methods suffer from intrinsic low reproducibility and production 
efficiency, and limited control on particle size that strongly bias industrial development. In the effort to meet industrial requirements, over the last two decades, membrane emulsification technology has taken the lead in particular in PLA and PLGA MP manufacturing (Liu et al. 2005a, b, 2006, 2011; Lloyd et al. 2014; Ramazani et al. 2016). The technique is based on a relatively simple concept. Emulsification is achieved by forcing a dispersed phase, usually an organic solution or a premixed coarse emulsion, into an aqueous continuous phase through a membrane of given porosity. The passage through the membrane produces homogeneous droplets, the size of which is determined by the membrane pore size and geometry, the droplet detachment regime from the membrane surface, and the flow shear resulting from the agitation method applied to the continuous phase (Hancocks et al. 2013). Additional attention should be taken in selecting the proper membrane wall material, depending on the polarity of the dispersed and continuous phases, as membrane wettability, charge and permeability influence droplet formation (Vladisavljević et al. 2012; Silva et al. 2017). Overall, ideal membranes should have a uniform pore size distribution over a wide range of sizes to grant tuneability of droplet size, low hydrodynamic resistance, high mechanical strength, thermal and chemical resistance, high tolerance to organic solvents, ease of surface modification and functionalization, constant wettability with respect to the dispersed and continuous phase, and low fabrication costs (Vladisavljević 2015). Shirasu Porous Glass (SPG) material meets the majority of the above requirements and for such a reason is widely employed for membrane production (Qi et al. 2014; Lu et al. 2017; Gu et al. 2018).

For a complete treatment of the method, readers may refer to Vladisavljević et al. (Vladisavljević et al. 2016) and Piacentini et al. (Piacentini et al. 2014, 2017).

Benefits of membrane emulsification include enhanced droplet size control, low shear stress and energy requirement, equipment setup flexibility. This technique is therefore suitable for high throughput production of precisely tuned and highly homogenous MP with sizes between $<1$ and 100 $\mu \mathrm{m}$ (Gasparini et al. 2008). Two main membrane emulsification modalities exist: moving continuous phase or moving membrane (Fig. 1). In the first, the continuous phase is kept under movement by stirring or unidirectional or pulsed flow. In addition, vibrating elements generate a mixing effect that favors the emulsification process of the droplets protruding from the membrane. The second modality consists in a membrane cartridge containing the inner phase that is maintained under rotational or vibrational motion in the continuous phase (Fig. 1). The moving membrane emulsification method is considered superior as it prevents droplet damage due to the shear when circulating the continuous phase, shows a higher scale-up reproducibility, and can limit

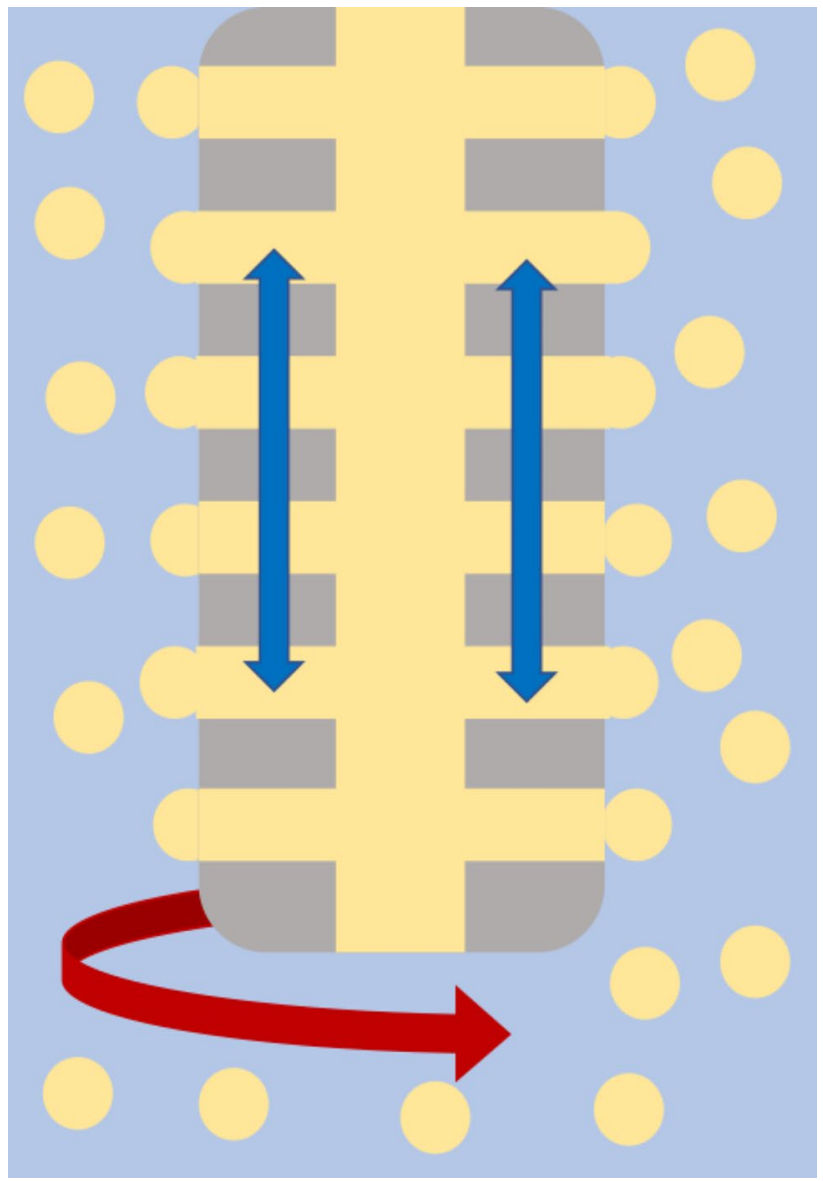

Fig. 1 Particle production using the membrane emulsification technology. The membrane is shown in grey, continuous phase in blue and dispersed phase in yellow. Two different process modalities exist: the moving continuous phase and the moving membrane. In the first, the external continuous phase is kept under mixing by a stirring bar or moved by a linear unidirectional or pulsed flow generated by a flow pump. In the second, it is the filter system to be maintained under rotational (red arrow) or vibrational (blue arrows) motion. In both the modalities, the movement generated is essential to allow the detachment of the droplets stemming from the membrane and their diffusion in the continuous phase. Adapted from Piacentini et al. (2014). (Color figure online)

manufacturing costs as a result of a reduced energy demand as well.

The energy involved is usually very low compared to other homogenization techniques. Indeed, this important aspect underpins the industrial development of this manufacturing technique.

Progresses towards industrialization allowed the development of several PLA and PLGA technology platforms. Batch and continuous operation devices are currently available. The first is made up of a pressurized chamber, in which a membrane separates the dispersed phase and a constantly stirred continuous phase (Fig. 2a-c). The continuous 


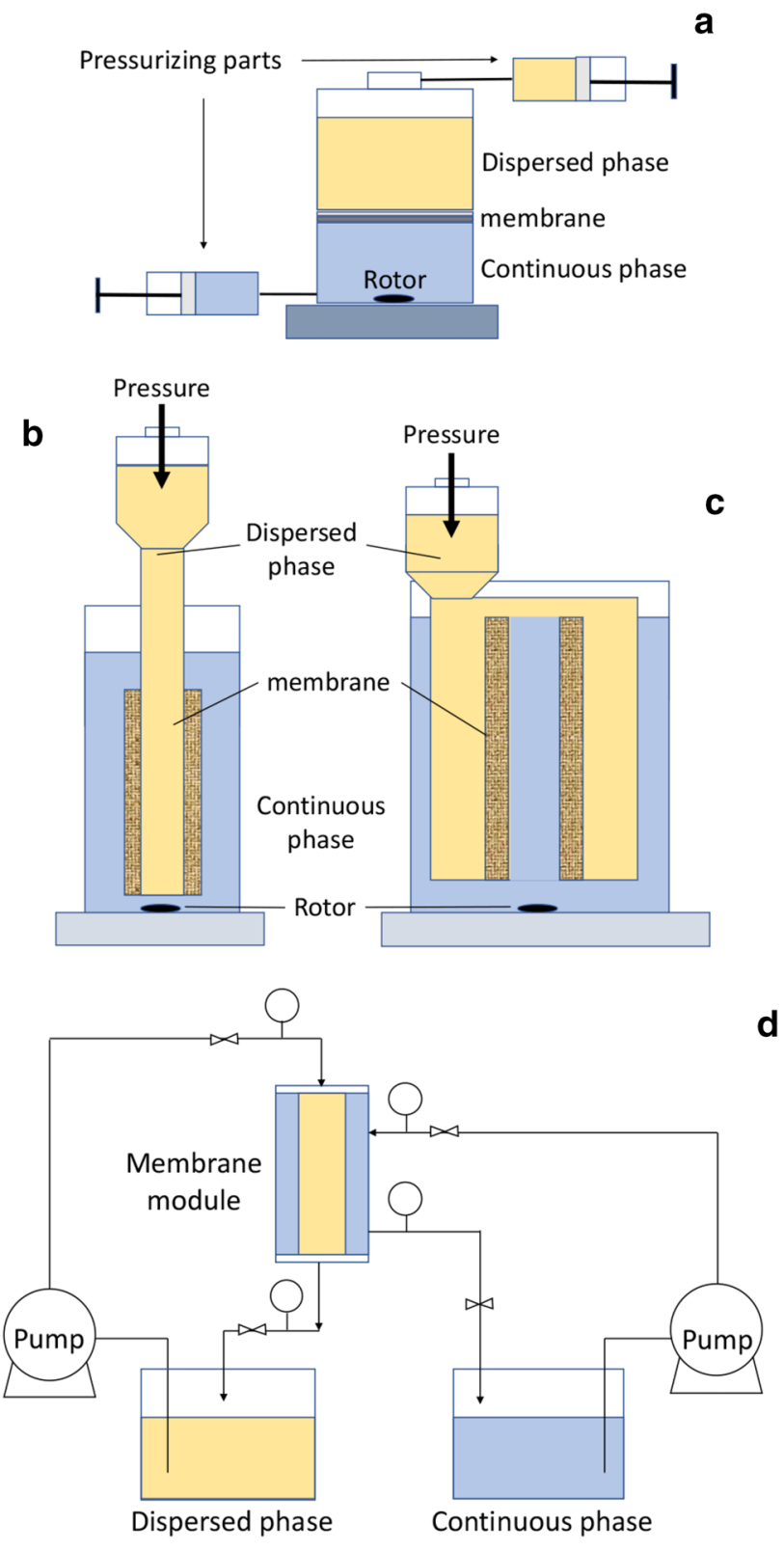

Fig. 2 Membrane emulsification devices. a-c Batch operation devices: the inner organic phase is pressurized through the membrane by a syringe or a controlled pumping system; the mixing effect is obtained by stirring the static continuous phase with a stirring bar; the organic solvent is evaporated and the dispersed particles recovered by filtration. d Continuous operation device: both the inner organic phase or the continuous phase flow through two separate loops that connect the respective reservoirs to the emulsifying chamber allowing continuous operation. Adapted from Piacentini et al. (2014)

operation device is instead a typical cross-flow apparatus in which the dispersed phase is continuously pumped through the membrane and recirculated (Fig. 2d) (Ho et al. 2013).

The undeniable attractiveness of the emulsion-based technologies is witnessed by the number of products in the market that exploit such platforms as also reported in Table 1.

The possibility to finely tune size and composition of PLA and PLGA MP by adopting proper multiple emulsification processes affords fabrication of complex composite particles. In this regard, a rotating membrane emulsification system was employed for the preparation of iron nanoparticle loaded PLGA MP for tumor arterial embolization and magnetic ablation (Liang et al. 2017).

W/o/w emulsions are generally employed for hydrophilic compounds, such as many proteins (Ma 2014) and insulin (Liu et al. 2006). Furthermore, a w/o/w emulsion followed by premix rotational membrane emulsification enabled the fabrication of bovine serum albumin loaded mPEG-PLGA MP possessing proper pulmonary delivery features (Zhao et al. 2018).

These evidences demonstrate that this technology shows great potential as it couples brilliant performances in the production of precisely tailored uniform MP with versatility and limited costs.

\section{Spray freeze-drying}

Potentially scalable technologies are today available which combine well known techniques into a one-step manufacturing process. One of the most promising for the preparation of PLGA and PLA MP is spray freeze-drying (SFD) of drug-polymer solutions/dispersions that enables a broad range of applications, particularly for proteins and biologics (Wanning et al. 2015). Spray freeze-drying is a well-established process since its first appearance in 1964 (Werly and Bauman 1964) in the food and pharmaceutical industry for processing and powder engineering (Ishwarya et al. 2015; Dutta et al. 2018).

The principle of combining spraying with lyophilization, rather than with common exsiccation processes, provides several advantages. Beyond the note improvement of drug solubilization and amorphization that minimizes potential phase separation phenomena (Vo et al. 2013), SFD shows its full potential in processing and encapsulation of unstable proteins and peptides for drug delivery and vaccination purposes (Cheow et al. 2011). Most important, SFD can provide additional control over MP morphology and size distribution. Compared to conventional freeze-drying, SFD is economically preferable in terms of time and energy consumption (Claussen et al. 2007). Moreover, the production of a flowable bulk powder, in place of filled vials, enables a considerable increase in production plant flexibility, allowing easy dosage adjustments.

In this regard, spray freeze-dried human growth hormone and recombinant human vascular endothelial growth factor loaded PLGA MP showed low burst release and the behavior 
could be controlled by prior tuning of spray-freezing conditions (Cleland et al. 2001; Costantino et al. 2004).

A comparison of SFD with SD showed that the lipidPLGA particles obtained by SFD exhibited improved characteristics in terms of size, yield, flowability, aqueous reconstitutibility, and aerosolization efficiency (Wang et al. 2012), supporting the usefulness of SFD even for the production of inhalable PLGA powders. Furthermore, SFD demonstrated superior performances compared to SD in encapsulating darbepoetin alfa, an erythropoiesis-stimulating protein, in PLGA MP in terms of yield and particle size control (Burke et al. 2004).

Beyond the highlighted virtues, a SFD caveat is the relative complexity of equipment setup at pilot/production scale, which demands particular care in the lab-to-plant transfer process, thing that can bear on manufacturing costs.

\section{Other technologies}

\section{Hot-melt extrusion}

A well-known method for the encapsulation of hydrophobic drugs in PLA and PLGA matrices is hot-melt extrusion (HME). The technique consists in a series of continuous processes in which micronized drugs are dispersed in a polymer melt, extruded, and then cooled down and ground or milled into fine particles (Wichert and Rohdewald 1990; Makadia and Siegel 2011). If spherical particles are desired, the obtained ground or milled particles can be dispersed in a hot polymer or surfactant solution (Crowley et al. 2007; Lang et al. 2014).

In fact, it is possible to produce injectable MP depots by coupling HME with micronization methods, such as wet milling or jet-milling in order to obtain spherical particles (Nykamp et al. 2002; Guo et al. 2017b). HME is a costeffective method characterized by the absence of an organic solvent, continuous operation, and easy scale up. However, several limitations should be accounted many of which relate to drug exposure to thermal treatment and the often large number of steps required to produce smooth spherical MP (Wischke and Schwendeman 2008).

Potentially, the method could suit not only the encapsulation of hydrophobic but even of hydrophilic drugs that could be dispersed in the polymer matrix as a micronized solid. Nevertheless, the use of high temperatures discourages the application to biomolecules and biologics. Moreover, it should be minded that non-porous particles are usually obtained, feature that could slow down excessively the release of water-insoluble drugs.

\section{Spray-congealing}

Another potentially appealing technique that to date has been sparingly employed for the production of PLA and PLGA MP is spray congealing (SC). This method consists in a unit operation in which a liquid melt is atomized into a cooling chamber. The liquid is atomized into a congealing gas, droplets are promptly frozen, and particles solidify upon removal of the gas. Several configurations exist in which a liquid melt or a solution can be processed. The congealing media in the cooling chamber change accordingly and can be a gas or a frozen non-solvent, which is usually layered with liquid nitrogen to favor the successive cryogenic solvent removal, see also the section referred to cryogenic solvent extraction (Cordeiro et al. 2013). In many ways, SC shows hybrid features between SD and HME. As such, SC is a platform suitable for the microencapsulation of thermosensitive compounds, particularly proteins and peptides (Yeo et al. 2001).

As anticipated above, a modified SC technique has been developed in the Alkermes' ProLease ${ }^{\circledR}$ platform (Johnson et al. 1997). This technology has been employed for the manufacturing of Nutropin Depot ${ }^{\circledR}$, a Genentech's somatotropin drug product discontinued in 2004. The Alkermes platform was also used in the Merck Serono's Prolease r-hFSH, a sustained release formulation of recombinant human follicle stimulating hormone for the treatment of infertility, and the Janssen's Procrit Prolease, a recombinant human erythropoietin to control red blood cells production, both discontinued at phase 1 clinical and pre-clinical stage, respectively.

\section{In situ forming microparticles}

Worth citing is a strategy that does not rely on any peculiar process or equipment, but consists in an injectable solution that precipitates in situ forming a sustained release MP depot (Royals et al. 1999; Jain et al. 2000; Luan and Bodmeier 2006).

Drug/polymer solutions are dissolved in water-miscible solvents, such as n-methyl pyrrolidone or dimethylsulfoxide (DMSO), that are then emulsified in an external oil phase. Upon injection, the solvent diffusion causes precipitation of the polymer resulting in MP entrapping the drug to be released. Naturally, safety issues limit types of solvents and oils that thus have to be carefully selected (Wischke and Schwendeman 2008).

This approach overcomes some drawbacks of conventional techniques, including manufacturing costs and complexities of manufacturing processes. Several FDA-approved long-acting depots exploiting this technology are available in the market (Table 4). An example is the leuprolide acetate depot which releases the drug over months. 
Table 4 PLA//PLGA based in situ forming depot technologies and products marketed or under clinical development (not intended to be fully exhaustive)

\begin{tabular}{|c|c|c|c|c|}
\hline Investigational or brand & API & Indication(s) & Encapsulation technology & Development stage \\
\hline Atridox $^{\circledR}$ & Doxycycline & Periodontitis & AtriGel $^{\circledR}$ & Marketed \\
\hline Atrisorb $^{\circledR}$ & Doxycycline & Periodontitis & AtriGel $^{\circledR}$ & Marketed \\
\hline CAM2029 & Ocreotide & $\begin{array}{l}\text { Acromegaly and neuroendo- } \\
\text { crine tumors }\end{array}$ & FluidCrystal $^{\circledR}$ & Phase I-II \\
\hline CAM2032 & Leuprolide acetate & Prostate cancer & FluidCrystal $^{\circledR}$ & Phase I-II \\
\hline CAM2038 & Buprenorphine & Opioid dependence & FluidCrystal $^{\circledR}$ & Approved \\
\hline CAM4072 & Setmelanotide & Genetic obesity & FluidCrystal $^{\circledR}$ & Phase I-II \\
\hline Eligard $^{\circledR}$ & Leuprolide acetate & Prostate cancer & AtriGel $^{\circledR}$ & Marketed \\
\hline mdc-iRM & Not known & Schizophrenia & $\mathrm{BEPO}^{\circledR}$ & Phase III \\
\hline mdc-CWM & Not known & Pain and inflammation & $\mathrm{BEPO}^{\circledR}$ & Phase II \\
\hline Perseris $^{\mathrm{TM}}$ & Risperidone & Schizophrenia & AtriGel $^{\circledR}$ & Approved \\
\hline Sublocade ${ }^{\circledR}$ & Buprenorphine & Opioid dependence & AtriGel $^{\circledR}$ & Marketed \\
\hline
\end{tabular}

\section{Advanced manufacturing technologies}

\section{Microfluidics}

Microfluidics is a technique that is quickly growing and that consents to prepare particles of the same dimensions and therefore characterized by a reproducible drug release pattern (Lee et al. 2016). To produce PLA/PLGA particles, a microfluidic device that may have different geometries is required. The device comprises of several microchannels, etched or molded in different materials such as glass, silicone or poly(dimethylsiloxane) (PDMS), that are connected together. These microchannels are filled in thanks to inlets and fluids flow rate is controlled by micropumps and microvalves until they are withdrawn through the device outlet (Swider et al. 2018). This relatively new strategy of PLA/PLGA MP production can be scaled up when PDMS devices are employed since their production is easy, cheap and grants the fabrication of channels with reproducible dimensions. This is on the contrary harder to obtain with glass devices. The limit of using PDMS microfluidics is their swelling behavior in contact with organic solvent such as methylene chloride. To avoid this problem, the microchannels inner surface can be coated with a PVA/glycerol solution (Duncanson et al. 2012; Li et al. 2015). Polymeric MP are produced exploiting single, double or multiple emulsions that can be formed in the device choosing the proper microchannel geometry. Particle dimensions can be easily tailored modifying the solvent nature, the polymer and stabilizer concentration, and the flow rate of the different solutions. Monodisperse droplets are obtained since the emulsion formation is strictly controlled passively or actively handling the flow rate, the volume ratio of the aqueous and organic phases, and the device geometry. The main difference between the active and passive technique is the
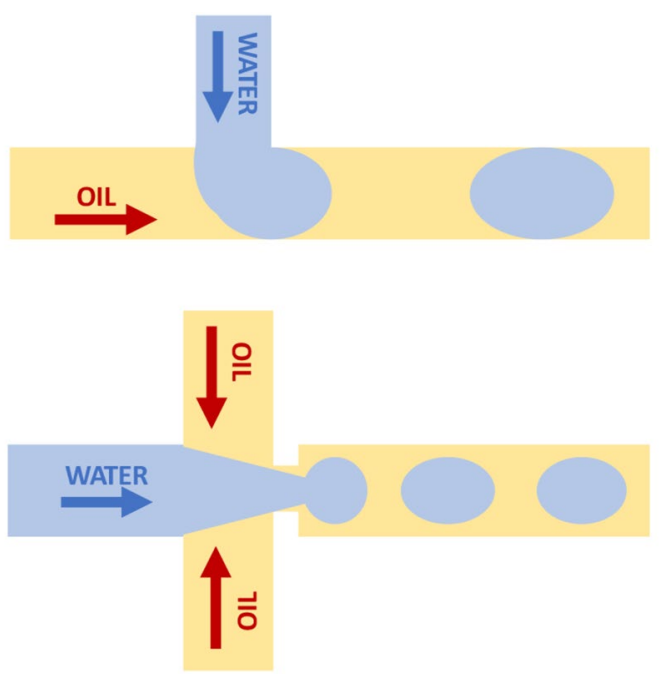

b

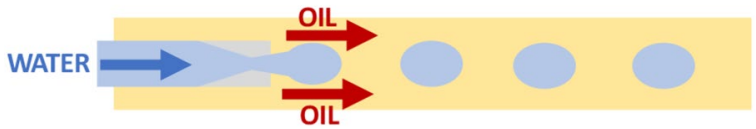

C

Fig. 3 Microfluidic channel geometries; a T-junction geometry: the aqueous phase flows orthogonally into the oil phase; $\mathbf{b}$ flow-focusing geometry: the oil phase enters orthogonally the channel while the aqueous phase flows coaxially into the oil phase flow; the oil phase flows through a bottleneck junction and the pressure drags the aqueous droplets into the oil stream; c co-flow geometry: the aqueous phase enters coaxially into the co-current oil phase flow; the oil phase pressure pushes the aqueous droplets into the parallel oil stream. Adapted from Swider et al. (2018)

use of additional accessories for the active technique such as microvalves, heaters that require energy to be actuated (Vladisavljević et al. 2013). Device microchannel geometry can be divided in T-junction, flow-focusing and co-flow 
geometries (Fig. 3). The T-junction microfluidic device possesses two inlets: the continuous phase flows through horizontally, while the organic phase containing the polymer is introduced from the second inlet and encounters the aqueous phase perpendicularly. In the flow focusing device, the continuous phase is introduced in the two side channels while the organic phase flows through the central channel. The organic phase is then forced to pass through a thin orifice by the symmetric shear forces of the aqueous phase meeting the organic solution from the two lateral channels (MartínBanderas et al. 2005; Keohane et al. 2014; Perez et al. 2015; $\mathrm{Li}$ et al. 2015). The flow-focusing geometry device usually consents to obtain smaller droplets and therefore smaller particles than T-junction microfluidics due to the shearing forces applied (Xu et al. 2009; Vladisavljević et al. 2013). In the co-flow system (third geometry), both phases flow in the same direction but in two different coaxial microchannels. The organic phase flows in the inner channel, while the continuous phase flows in the outer microchannel. To obtain double or multiple emulsions, different geometries can be combined, such as the flow-focusing microchannels with the co-flow system (Duncanson et al. 2012).

\section{Electrospray}

The main difference between electrospinning and electrospray is the polymer solution concentration. To obtain particles, it is necessary to work with a low polymer concentration. The electric field applied to the syringe containing the polymer solution pushes the polymer outside the syringe needle to form monodispersed particles on the receiving grounded electrode (Oliveira and Mano 2011). Electrospray has the great advantage of being a one-step process. By tuning the voltage intensity applied, the solution flow rate, the drying time and rate, that depend on the distance between the needle tip and the collection plate and on the solvent vapor pressure, respectively, it is possible to produce particles with specific features in terms of dimensions and morphology (Berkland et al. 2004; Xie et al. 2010). The use of concentric coaxial nozzle conveying two different fluids (i.e., the inner one that is surrounded by the outer fluid) is an evolution of the electrospray process (Lee et al. 2010; Han et al. 2016). The encapsulation efficiency is commonly $100 \%$ and particles are characterized by a core of API surrounded by a PLA/PLGA outer layer. Electrospray apparatuses equipped with a coaxial nozzle are particularly indicated for the encapsulation of peptides and proteins, considering the high drug loading and the limited stress to which the drug is exposed (Xie and Wang 2007; Xie et al. 2008; Ye et al. 2010). Recently, ranibizumab has been encapsulated with $70 \%$ efficiency and a high activity preservation (Zhang et al. 2015).

\section{Microfabrication methods}

Soft lithography is a family of techniques, including microcontact printing, micro-molding, nano-transfer printing, having in common the use of an elastomeric mold. Soft lithography is for instance the technique used to produce the microfluidic device mentioned above. The material used to produce the mold is commonly PDMS because of its low cost, biocompatibility, low toxicity, chemical inertness, and its mechanical flexibility and durability. PDMS mold can be fabricated with micro- or nanostructures to produce micro- or nanoparticles as reported in the paper by Guan et al. (Guan et al. 2006). Associating both micro-contact printing and micro-transfer molding, PLGA particles of different shape and size were produced evidencing the versatility of these techniques with respect to the lab-scale methods (Guan et al. 2006). To speed up and facilitate particle recovery from the mold, a template of gelatin was prepared exploiting the sol-gel phase transition of hydrogels. In this way, once the organic solvent containing PLGA evaporated, particles were recovered dissolving the gelatin mold in water at $40{ }^{\circ} \mathrm{C}$ and centrifugating the resultant suspension. This strategy is easily scalable, cheap and the conditions to which API are exposed are mild, making this technique advantageous to prepare MP for drug delivery (Acharya et al. 2010, 2011). These microfabrication methods are also reported in literature under the acronym PRINT that stands for Particle Replication In Nonwetting Templates (Fig. 4) (Enlow et al. 2011; Perry et al. 2011; Swider et al. 2018). This technology is mainly adopted for the production of nanoparticles but can also be applied to produce MP loaded with different API, both hydrophilic and lipophilic (e.g., doxorubicin) (Enlow et al. 2011). The main difference with respect to the processes described previously is the use of a different material to produce the mold. In particular, highly fluorinated perfluoropolyether (PFPE) elastomer is employed instead of PDMS. This new elastomer does not swell in the presence of organic solvents and is therefore advantageous in comparison to PDMS. It also possesses a low surface energy, a high gas permeability, a low toxicity, good mechanical and elastic properties and is chemically stable and resistant to solvents. The PRINT platform consents to produce particles of potentially any shape and size characterized by high loading efficiency with low polydispersity index. Monodisperse particles have the great advantage of showing a predictable drug release pattern and are therefore very suitable for drug delivery applications (Swider et al. 2018).

\section{Inkjet technology}

Inkjet printing is another technology that consents to control the shape and the dimensions of the particles produced (Ramazani et al. 2016; Gupta et al. 2017). The ink consists 


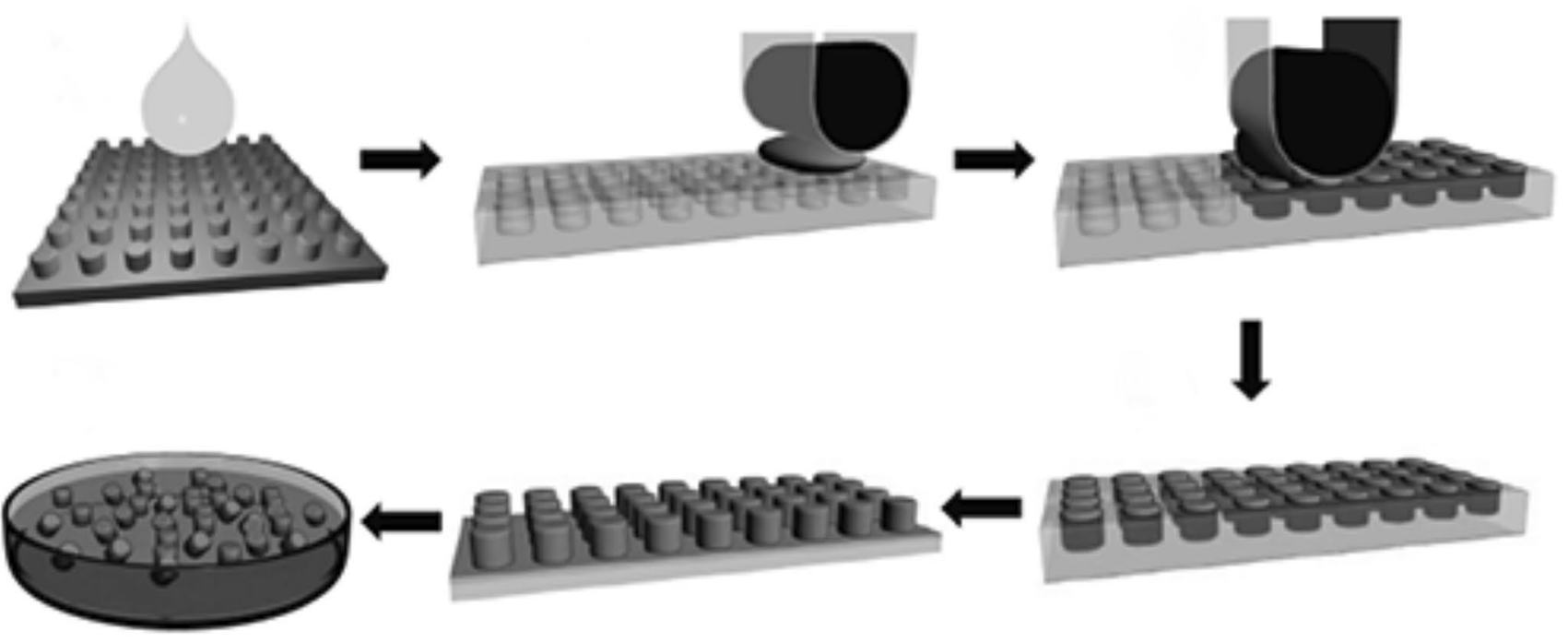

Fig. 4 Particle production using the PRINT method. The mold is initially prepared using PDMS, gelatin or PFPE by wetting the silicon wafer with micro- and nanosized patterns and is photocured to generate an elastomeric PRINT mold; then a solution of the polymer and the API is poured in the mold cavities using a film-split technique against a high-surface-energy polyethylene terephthalate counter sheet; particles of the desired shape and dimensions are obtained by

in an organic solution or in a w/o emulsion containing the polymer that is PLA or PLGA and the API. The inkjet technology has first been proposed by Berkland et al. with the name of Precision Particle Fabrication ${ }^{\circledR}$ (PPF) technology (Berkland et al. 2001). Using this technique, PLGA MP with dimensions in the range 30-85 $\mu \mathrm{m}$ were obtained starting from an emulsion. In particular, an ultrasonic transducer was employed to break the liquid jet emitted from the nozzle into droplets. The nozzle was sunk in a water bath containing a stabilizer where the solvent was progressively evaporated to recover monodispersed particles (Berkland et al. 2007). Besides ultrasounds, a piezoelectric actuator can be used to break the inkjet in small droplets. In this case, several parameters of the ink such as volatility, viscosity and surface tension have to be optimized to be processable. With a single $30 \mu \mathrm{m}$ nozzle, 24,000 drops per second corresponding to 86 million particles or $8 \mathrm{~mL} / \mathrm{h}$ can be generated. Using this kind of nozzle submerged in an aqueous phase stabilized with polyvinyl alcohol, monodispersed particles with dimensions of about $15 \mu \mathrm{m}$ were obtained (Böhmer et al. 2010). Palmer et al. also used a piezoelectric actuator to produce octreotide acetate and ciclosporin A loaded polyester particles. Here, the API and the polymer were solubilized in DMSO and inkjetted in a transverse anti-solvent flow that was water or tert-butanol/water solution (Fig. 5). The possibility to scale-up this technology was studied using an inkjet device featuring 256 nozzles working at 2-4 kHz frequency producing more than 1 million particles per second (Palmer solvent evaporation, photocuring or temperature quenching. The solid particles are removed by contact with an adhesive layer and freed by dissolving the adhesive layer. Reprinted by permission from Springer Nature: Springer eBook, Pharmaceutical Powder and Particles by Anthony J. Hickey and Stefano Giovagnoli, American Association of Pharmaceutical Scientists, 2018

et al. 2017). With the same scale-up purpose, Orbis Biosciences, Inc. (Orbis Biosciences 2019), founded by Berkland and Fishback, has developed an inkjet device able to produce $\mathrm{kg} / \mathrm{h}$ and even $\mathrm{kg} / \mathrm{min}$ particles with dimensions comprised in the range $10 \mu \mathrm{m}$ to $1 \mathrm{~mm}$. The other important advantages of this technique are the absence of material wastage, reduction of manufacturing cost and process steps (Lee et al. 2012; Qi et al. 2018). A variant of the process previously described has been reported by Lee et al. Droplets were produced using a continuous mode piezoelectric device and particles were recovered after $2 \mathrm{~h}$ drying of the ink that was printed on a glass slide. The particles showed distinctive paclitaxel release rate according to shape (Lee et al. 2012).

\section{Combined technologies}

PLA and PLGA MP were produced using different combined technologies. PLGA particles were prepared using a inkjet process followed by thermally induced phase separation (TIPS). Briefly, a PLGA solution in dimethyl carbonate was inkjetted using a piezoelectric actuator and droplets were collected in liquid nitrogen to freeze the solvent, obtaining phase separation. The solvent was finally removed by vacuum freeze-drying to recover porous particles (Go et al. 2014). Spray-drying is an industrial production method of PLA/PLGA particles that suffers of some drawbacks such as the large particle size distribution and morphology related to the atomization technology. To obtain more 


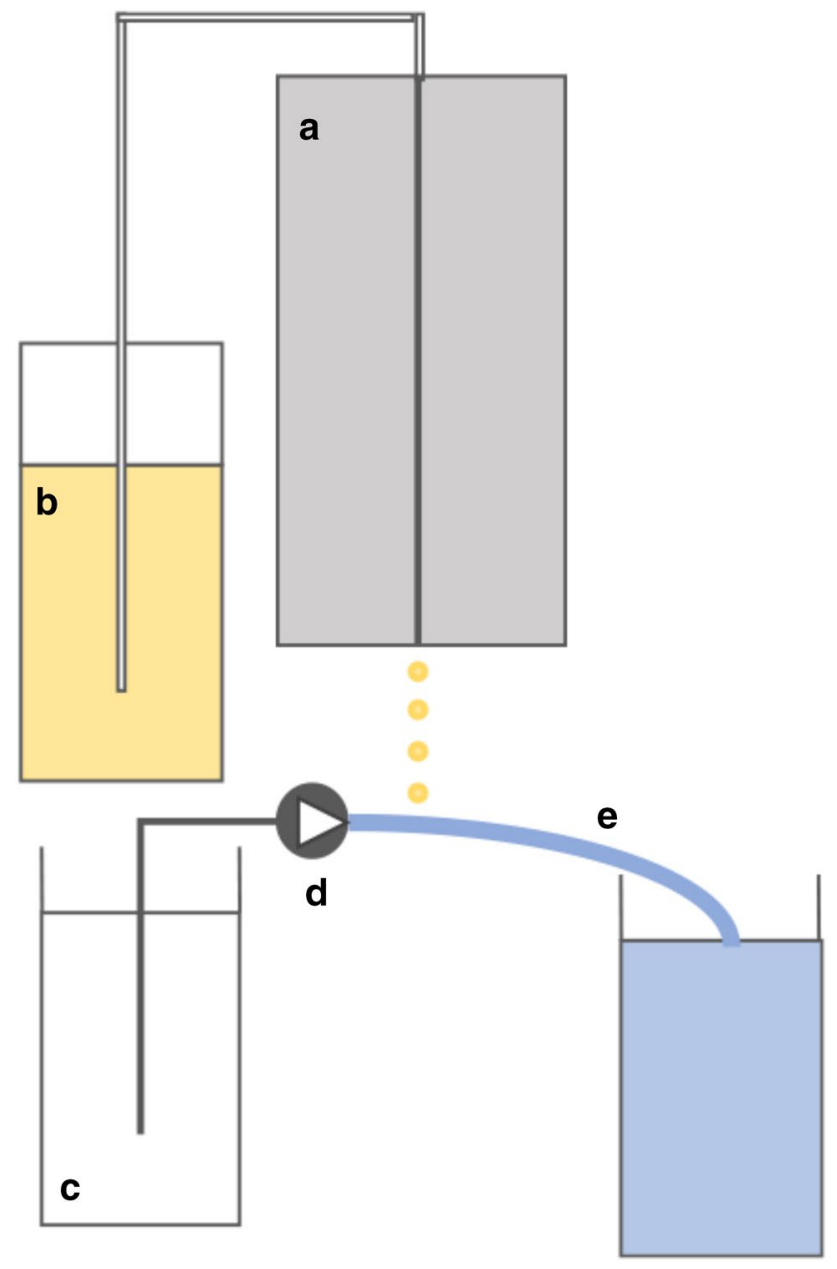

Fig. 5 Particle production using the inkjet technology. The piezoelectric actuator a nebulizes the polymer and the API solution, $\mathbf{b}$ in a transverse anti-solvent flow e, pumped with a pulseless micropump d from an anti-solvent reservoir (c). Adapted from Palmer et al. (2017)

homogeneous particle size and morphology, it is possible to combine SD with several droplet generation processes able to generate monodisperse droplets. To this aim, inkjet droplet generators or microfluidic jet were combined with SD obtaining uniform particles with tuneable characteristics for the encapsulation and controlled delivery of API (Liu et al. 2015). Another combined technology consists in the production of microdroplets with uniform dimensions using an ultra-fine particle processing system (UPPS) followed by solvent evaporation in a spray-dryer. The use of UPPS allows to evaporate the solvent at ambient temperature as a result of the long path the droplets have to travel. UPPS uses a nozzle that feeds the solution or suspension at the center of a rotating disk (1000-16,000 rpm) that drives the fluid towards its circumference obtaining a thin fluid layer that is nebulized in fine droplets. The droplets travel in the body cavity of the UPPS where endocentric airflow and tangent air vortex progressively dry the droplets (Zhu et al. 2015).
These combined technologies were used to produce risperidone (Fu et al. 2012) and exenatide loaded PLGA MP (Zhu et al. 2015) with good encapsulation efficiency, homogeneous dimensions and prolonged in vitro release. This combined technology is particularly advantageous because heat sensitive macromolecules can be encapsulated under mild conditions (Zhu et al. 2015).

\section{Technological and regulatory barriers}

In recent years, the interest in depot drug delivery systems has experienced a noticeable growth in light of novel market opportunities. The extension of life expectancy, the general population aging, and striking risk factors, especially across industrialized areas, have led to a significant increase of chronic ailments. Chronic conditions place emphasis on the required high compliance of treatment in terms of dosing frequency and self-medication. Therefore, to achieve such a goal, prolonged and sustained action and low-invasive and easy administration modalities are compulsory. In this scenario, depot systems find a logical prominent position, which explains the estimated growth of this market area over the next few years (Greystone Research Associates 2018).

Biodegradable PLA and PLGA depots assume a natural leading role in this development pipeline for the aforementioned properties of such polymers and the vast possibility of formulation and modulation of their drug release behavior. Such a flexibility and versatility are witnessed by the several proprietary technologies that have been employed to produce a number of marketed PLGA and PLA sustained release depots (Table 1). The possibility of a long-term sustained release and safety of these formulations raise attractive perspectives for the treatment of chronic or semi-chronic conditions particularly when precise adherence to therapy is required, e.g., the case of antipsychotic therapies. On the other hand, compliance of administration modality can be met by existing and emerging smart needle-free injection technologies, which enable a dramatic reduction of invasiveness and sterility concerns as well as improved usability (Barolet and Benohanian 2018). These technologies exploit the transient permeation effect provoked by high speed jets of liquids or colliding particles. Skin permeabilization is the result of the shockwave produced by the liquid or gas/particles impinging the stratum corneum and causing a reversible disruption of the skin layers over a microseconds timeframe (Fig. 6). The propelling power is provided by mechanical forces such as spring actuated plungers, compressed gas, e.g. nitrogen and carbon dioxide, and electrical power (Kale and Momin 2014; Schoubben et al. 2015).

Modern injectors show considerable advantages compared to syringes or pen injectors (Guo et al. 2017a), such as a disposable nozzle, no sterility preservation issues, and 

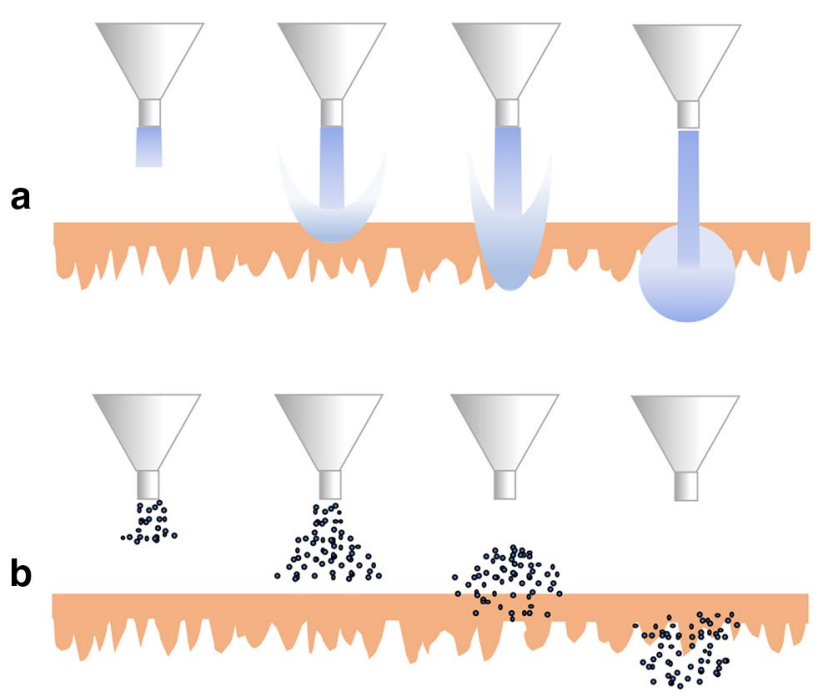

Fig. 6 Needle-free injection device injecting a high-speed jet of liquid (a) or of powder (b). In the first case, a piston pushes the liquid through a nozzle, which produces a jet at $>100 \mathrm{~m} / \mathrm{s}$ (velocity); the jet starts the formation of a hole on the skin through surface erosion, fracture, or other skin disruptive processes; a few tens of microseconds of prolonged impingement of the jet provokes progressive increase of hole depth; the liquid accumulates in the skin hole slowing down the jet and further increase of the hole is stopped; the consequent stagnation favors diffusion of the liquid into the skin. In the case of powder injections, a chamber filled with the powder is pressurized with a gas and a jet is generated by rupture of a membrane set; the particles impinge the skin surface leading to formation of a hole into the skin depositing in a spherical pattern, penetrate across the stratum corneum, and distribute completely into the stratum corneum and the viable epidermis; to produce a proper powder jet, particle densities of about $1 \mathrm{~g} / \mathrm{cc}$ and a mean diameter $>20 \mu \mathrm{m}$ are desirable. Adapted from Kale and Momin (2014)

patient-friendly and high compliance features. Several FDAapproved injectors have been marketed and regulated by specific guidelines (FDA Guidance for Industry 2013).

Therefore, today technologies are available to move PLA/ PLGA MP depots towards a new industrial era. Unfortunately, the technical and regulatory gap that separates injectable PLA/PLGA MP depots from well-established pharmaceutical products, e.g. oral, is still dramatically wide. Official validated methods for MP testing, in particular dissolution and stability assays, are lacking. Non-compendial drug release methods such as dialysis sac, reverse dialysis sac, and sample-and-separate have been proposed (Andhariya and Burgess 2016), but no standardization is warranted. A possible option may be the flow-through cell based USP apparatus 4 that has been found to grant good sink conditions, minimize microsphere aggregation, better mimic in vivo conditions, and it better suited long-term release studies (Rawat et al. 2011; Tomic et al. 2016). Recently, even the use of an orbital shaker based method has been positively evaluated, yet its application is far behind standardization (Garner et al. 2018).
Due to the long duration of action of PLA/PLGA depots, accelerated studies are desirable to shorten the testing period either for release or stability assessment. However, albeit some studies have demonstrated feasibility of accelerated release or stability assays, since such experiments are performed at increased temperatures, reliability and consistency of such approaches should be always checked and no standardization has been achieved so far. The reason is the effect of temperature on the low glassy polyester matrix, which tends to anneal if the testing temperature approaches the polymer glass transition temperature. Such critical features apply also to stability testing of MP. In this regard, directions are provided by the ICH Q1A guidelines that establish the proper conditions to assess product quality (ICH Q1A 2003).

This lack of compendial or biorelevant in vitro testing and related characterization standards as well as of adequate guidelines deeply hinder developability of PLA/PLGA depots. Indeed, bioequivalence assessment for these products is basically unmet. The reason is that PLGA/PLA heterogeneity and differences in manufacturing methods deeply influence the product physicochemical properties and thus release behavior and bioavailability. Even under high qualitative and quantitative sameness, bioequivalence may not be ensured (Zheng et al. 2017). Furthermore, adequate clinical settings along with sterilization requirement are another unmet challenge that are under intense evaluation.

All such reasons explain the to date absence of PLGA/PLA based generic drug products. The increased effort directed to overcome such considerable challenges has led to dedicated initiatives by regulatory agencies. The FDA's OGD has issued seven specific recommendations for MP products as guidance on bioequivalence study design (Wang et al. 2016) and it is working to develop recommendations for PLA/PLGA-based drug products.

Recognizing these challenges, a FDA's regulatory science research program was started in 2012 under the generic drug user fee amendments and is currently under implementation by OGD to provide new tools to support generic product development. Under this aegis, OGD has granted multiple research projects on PLA/PLGA based drug products involving MP, implants, and in situ gelling systems. These projects encompassed development of in vitro-in vivo correlations, in vitro release testing methods, characterization of PLA/PLGA polymers and formulations, and modeling and simulation of PLA/PLGA-based drug products. In spite of such efforts, none of the ongoing programs has completed its task so far, even though progresses in the field are continuous. Recently, an approach based on reverse engineering has been proposed to support generic development for 1-month Lupron ${ }^{\circledR}$ depot (Zhou et al. 2018). This could represent a valuable strategy to be expanded to other PLA/PLGA based depots. 


\section{Current scenario and future perspectives}

The overall picture drawn so far looks rather twisted and the road to generic PLA/PLGA MP based products seems winding and full of barriers. These products may allow different routes of administration, such as pulmonary and parenteral, and a sustained effect that is highly beneficial to the treatment of chronic disease conditions. Availability of generic products, especially for LAI, would ease patient's access and adherence to therapy, considering the high production and market costs. This is particularly true if considering schizophrenic patients who have to be treated under rigorous medical control. A single long-term injection would improve compliance and nearly erase the non-adherence risk.

In particular, LAI products show a higher cost/effectiveness compared to oral antipsychotic treatment (Yang et al. 2009) with reduced hospital admissions, relapse rates and length of inpatient stay, especially for patients who may be at risk of non-adherence with oral antipsychotics (Peng et al. 2011; Nikolić et al. 2017).

Cost comparison of antipsychotic LAI versus other pharmaceutical forms clearly shows that LAI products may be more expensive compared to tablets or other injectables, however the difference is by far counterbalanced by the lower costs that burden on the health system for hospitalization, home visit and medical assistance (Ravasio et al. 2015; Patel et al. 2018; González et al. 2018). Similar considerations have been found to apply even in other therapeutic areas such as cancer and contraception (Ayyagari et al. 2017; Di Giorgio et al. 2018).

The clinical benefits of LAI are evident although their employment is still controversial as dosing flexibility and self-management skills might be undermined. Therefore, clinicians ought to be required to prescribe LAI treatments on a case by case basis by evaluating patient's risks and benefits (Mutsatsa 2017).

Naturally, this overall positive cost/effectiveness profile of LAI applies to PLA/PLGA MP based LAI as well. For this reason and the expired or expiring patent coverage for several products marketed in the 90s, the European Medicine Agency and the FDA are increasingly committed in the establishment of proper standards and guidelines useful to underpin the generic development of these peculiar products (EMA 2014).

As we have tried to point out in this review, the unmet aspects of PLA/PLGA MP based product development are reciprocally interconnected and influential on either the regulatory or manufacturing side. In fact, the progress of manufacturing techniques is hindered not only by the high complexity of such products but also, to a significant extent, by the absence of adequate standards and specific regulations, which impact the assessment of suitable clinical settings as well. Such a scenario is complicated further by the high costs associated with the technology employed to date for the manufacturing of PLA/PLGA MP based products. As highlighted above, victims of such miscalculations have been the discontinued Genentech's Nutropin Depot ${ }^{\circledR}$, Merck Serono's Prolease r-hFSH, and Janssen's Procrit Prolease, all employing the Alchermes' Prolease ${ }^{\circledR}$ platform. Unsustainable management costs were at the origin of Nutropin discontinuation and, beyond undeclared issues, they also likely impaired the development of the other products that never reached the market.

This negative experience suggests that the choice of the manufacturing technology should be accurately weighed and it should evolve withholding an intrinsic simplicity and control. These aspects are crucial as they considerably impact the health technology assessment (HTA) process. In this regard, we have already underlined the importance of a proper evaluation of the manufacturing technology costs in HTA for advanced pharmaceutical forms that requires the contribution of an expert working side by side with clinicians (Panzitta et al. 2015). Unfortunately, still this aspect demands full implementation.

Seeing the glass half-full, the new opportunities driven by the novel emerging manufacturing technologies concisely described in this review will surely push forward the development of innovative and more reliable manufacturing methods for PLA/PLGA MP based depots. The contribution of the technology advancements recorded in the last years hold promises for the future assessment of robust and high-throughput manufacturing processes. Proper cost management favored even by new technological solutions may grant a bright future development for techniques such as SD and SCF that, albeit at present demanding, clearly hold considerable advantages compared with other techniques, especially considering the current tendency towards continuous manufacturing. In addition, microfluidics and membrane emulsification methods and combined techniques, such as TIPS and UPPS may help to meet the so far unmet demand for lean and efficient PLA/PLGA based products manufacturing system.

However, the future of this promising products is pending upon the fulfilment of updated and novel quality standards and guidelines for the consolidation of development processes.

\section{Compliance with ethical standards}

Conflict of interest All authors (S. Giovagnoli, A. Schoubben, and M. Ricci) declare that they have no conflicts of interest.

Statement of human and animal rights This article does not contain any studies with human and animal subjects performed by any of the authors. 
Open Access This article is distributed under the terms of the Creative Commons Attribution 4.0 International License (http://creativecommons. org/licenses/by/4.0/), which permits use, duplication, adaptation, distribution and reproduction in any medium or format, as long as you give appropriate credit to the original author(s) and the source, provide a link to the Creative Commons license and indicate if changes were made.

\section{References}

Acharya G, Shin CS, McDermott M et al (2010) The hydrogel template method for fabrication of homogeneous nano/microparticles. $\mathrm{J}$ Control Release 141:314-319. https://doi.org/10.1016/j.jconr el.2009.09.032

Acharya G, McDermott M, Shin SJ et al (2011) Hydrogel templates for the fabrication of homogeneous polymer microparticles. Methods Mol Biol 726:179-185. https://doi.org/10.1007/978-1-61779 $-052-2 \_12$

Adami R, Liparoti S, Reverchon E (2011) A new supercritical assisted atomization configuration, for the micronization of thermolabile compounds. Chem Eng J 173:55-61. https://doi.org/10.1016/j. cej.2011.07.036

Albertini B, Iraci N, Schoubben A et al (2015) $\beta$-cyclodextrin hinders PLGA plasticization during microparticle manufacturing. J Drug Deliv Sci Technol 30:375-383. https://doi.org/10.1016/j. jddst.2015.07.022

Al-Khattawi A, Bayly A, Phillips A, Wilson D (2018) The design and scale-up of spray dried particle delivery systems. Expert Opin Drug Deliv 15:47-63. https://doi.org/10.1080/17425 247.2017.1321634

Allahyari M, Mohit E (2016) Peptide/protein vaccine delivery system based on PLGA particles. Hum Vaccin Immunother 12:806-828. https://doi.org/10.1080/21645515.2015.1102804

Allison SD (2008) Effect of structural relaxation on the preparation and drug release behavior of poly(lactic-co-glycolic)acid microparticle drug delivery systems. J Pharm Sci 97:2022-2035. https:// doi.org/10.1002/jps.21124

Anderson JM, Shive MS (2012) Biodegradation and biocompatibility of PLA and PLGA microspheres. Adv Drug Deliv Rev 64:72-82. https://doi.org/10.1016/j.addr.2012.09.004

Andhariya JV, Burgess DJ (2016) Recent advances in testing of microsphere drug delivery systems. Expert Opin Drug Deliv 13:593608. https://doi.org/10.1517/17425247.2016.1134484

Avgoustakis K (2015) Polylactic-co-glycolic acid (PLGA). In: M. Mishra (ed) Encyclopedia of biomedical polymers and polymeric biomaterials, 11 volume set. Taylor \& Francis Group, Boca Raton

Ayyagari R, Neary M, Li S et al (2017) Comparing the cost of treatment with octreotide long-acting release versus lanreotide in patients with metastatic gastrointestinal neuroendocrine tumors. Am Health Drug Benefits 10:408-415

Baker GL, Vogel EB, Smith MR III (2008) Glass transitions in polylactides. Polym Rev 48:64-84. https://doi.org/10.1080/15583 720701834208

Barolet D, Benohanian A (2018) Current trends in needle-free jet injection: an update. Clin Cosmet Investig Dermatol 11:231-238. https://doi.org/10.2147/CCID.S162724

Baxendale A, van Hooff P, Durrant LG et al (2011) Single shot tetanus vaccine manufactured by a supercritical fluid encapsulation technology. Int J Pharm 413:147-154. https://doi.org/10.1016/j. ijpharm.2011.04.053

Benvenutti DF, Bresolin TMB, Corrêa R et al (2018) A novel stabilizing approach to improve the manufacturing of biodegradable microparticles entrapping plasticizing active molecules: the case of 4-methoxychalcone. J Pharm Innov. https://doi.org/10.1007/ s12247-018-9346-9

Berkland C, Kim K, Pack DW (2001) Fabrication of PLG microspheres with precisely controlled and monodisperse size distributions. J Control Release 73:59-74

Berkland C, Pack DW, Kim KK (2004) Controlling surface nanostructure using flow-limited field-injection electrostatic spraying (FFESS) of poly(D, L-lactide-co-glycolide). Biomaterials 25:5649-5658. https://doi.org/10.1016/j.biomateria 1s.2004.01.018

Berkland C, Pollauf E, Raman C et al (2007) Macromolecule release from monodisperse PLG microspheres: control of release rates and investigation of release mechanism. J Pharm Sci 96:11761191. https://doi.org/10.1002/jps.20948

Bilati U, Allémann E, Doelker E (2005) Strategic approaches for overcoming peptide and protein instability within biodegradable nano- and microparticles. Eur J Pharm Biopharm 59:375388. https://doi.org/10.1016/j.ejpb.2004.10.006

Böhmer MR, Steenbakkers JAM, Chlon C (2010) Monodisperse polymeric particles prepared by ink-jet printing: double emulsions, hydrogels and polymer mixtures. Colloids Surf B Biointerfaces 79:47-52. https://doi.org/10.1016/j.colsu rfb.2010.03.021

Briken P, Berner W, P278 Study Group (2012) Double-blind, controlled, clinical trial planned in germany to investigate the efficacy of psychotherapy combined with triptorelin in adult male patients with severe pedophilic disorders: presentation of the study protocol. Isr J Psychiatry Relat Sci 49:306-313

Burke PA, Klumb LA, Herberger JD et al (2004) Poly(lactide-coglycolide) microsphere formulations of darbepoetin alfa: spray drying is an alternative to encapsulation by spray-freeze drying. Pharm Res 21:500-506. https://doi.org/10.1023/B:PHAM.00000 19305.79599.a5

Campardelli R, Reverchon E (2017) Instantaneous coprecipitation of polymer/drug microparticles using the supercritical assisted injection in a liquid antisolvent. J Supercrit Fluids 120:151-160. https://doi.org/10.1016/j.supflu.2016.11.005

Campardelli R, Reverchon E, Porta GD (2012) Biopolymer particles for proteins and peptides sustained release produced by supercritical emulsion extraction. Proc Eng 42:239-246. https://doi. org/10.1016/j.proeng.2012.07.415

Campardelli R, Della Porta G, Gomez V et al (2013) Encapsulation of titanium dioxide nanoparticles in PLA microspheres using supercritical emulsion extraction to produce bactericidal nanocomposites. J Nanopart Res 15:1987. https://doi.org/10.1007/ s11051-013-1987-5

Campardelli R, Oleandro E, Reverchon E (2016) Supercritical assisted injection in a liquid antisolvent for PLGA and PLA microparticle production. Powder Technol 287:12-19. https://doi. org/10.1016/j.powtec.2015.09.035

Capan Y, Jiang G, Giovagnoli S et al (2003) Preparation and characterization of poly(D, L-lactide-co-glycolide) microspheres for controlled release of human growth hormone. AAPS PharmSciTech 4:E28. https://doi.org/10.1208/pt040228

Casagrande S, Tiribuzi R, Cassetti E et al (2017) Biodegradable composite porous poly(DL-lactide-co-glycolide) scaffold supports mesenchymal stem cell differentiation and calcium phosphate deposition. Artif Cells Nanomed Biotechnol. https://doi org/10.1080/21691401.2017.1417866

Casettari L, Castagnino E, Stolnik S et al (2011) Surface characterisation of bioadhesive PLGA/chitosan microparticles produced by supercritical fluid technology. Pharm Res 28:1668-1682. https ://doi.org/10.1007/s11095-011-0403-z

Chattopadhyay P, Huff R, Shekunov BY (2006) Drug encapsulation using supercritical fluid extraction of emulsions. J Pharm Sci 95:667-679. https://doi.org/10.1002/jps.20555 
Chen A-Z, Kang Y-Q, Pu X-M et al (2009a) Development of $\mathrm{Fe}_{3} \mathrm{O}_{4}$-poly(L-lactide) magnetic microparticles in supercritical $\mathrm{CO}_{2}$. J Colloid Interface Sci 330:317-322. https://doi. org/10.1016/j.jcis.2008.10.085

Chen A-Z, Li Y, Chau F-T et al (2009b) Microencapsulation of puerarin nanoparticles by poly(L-lactide) in a supercritical $\mathrm{CO}_{2}$ process. Acta Biomater 5:2913-2919. https://doi.org/10.1016/j.actbi o.2009.04.032

Chen A-Z, Li Y, Chen D, Hu J-Y (2009c) Development of core-shell microcapsules by a novel supercritical $\mathrm{CO}_{2}$ process. J Mater Sci Mater Med 20:751-758. https://doi.org/10.1007/s1085 6-008-3633-9

Chen A-Z, Li L, Wang S-B et al (2012a) Study of $\mathrm{Fe}_{3} \mathrm{O}_{4}-$ PLLAPEG-PLLA magnetic microspheres based on supercritical $\mathrm{CO}_{2}$ : preparation, physicochemical characterization, and drug loading investigation. J Supercrit Fluids 67:139-148. https:// doi.org/10.1016/j.supflu.2012.04.009

Chen A-Z, Pu X-M, Yin G-F et al (2012b) Study of lysozyme-polymer composite microparticles in supercritical $\mathrm{CO}_{2}$. J Appl Polym Sci 125:3175-3183. https://doi.org/10.1002/app.36492

Chen A-Z, Wang G-Y, Wang S-B et al (2012c) Formation of methotrexate-PLLA-PEG-PLLA composite microspheres by microencapsulation through a process of suspension-enhanced dispersion by supercritical $\mathrm{CO}_{2}$. Int J Nanomed 7:3013-3022. https://doi.org/10.2147/IJN.S32662

Chen A-Z, Zhao C, Wang S-B et al (2013a) Generation of porous poly-L-lactide microspheres by emulsion-combined precipitation with a compressed $\mathrm{CO}_{2}$ antisolvent process. J Mater Chem B 1:2967-2975. https://doi.org/10.1039/C3TB20468E

Chen F, Yin G, Liao X et al (2013b) Preparation, characterization and in vitro release properties of morphine-loaded PLLAPEG-PLLA microparticles via solution enhanced dispersion by supercritical fluids. J Mater Sci Mater Med 24:1693-1705. https://doi.org/10.1007/s10856-013-4926-1

Cheow WS, Ng MLL, Kho K, Hadinoto K (2011) Spray-freeze-drying production of thermally sensitive polymeric nanoparticle aggregates for inhaled drug delivery: effect of freeze-drying adjuvants. Int J Pharm 404:289-300. https://doi.org/10.1016/j. ijpharm.2010.11.021

Claussen IC, Ustad TS, Strømmen I, Walde PM (2007) Atmospheric freeze drying - a review. Drying Technol 25:947-957. https:// doi.org/10.1080/07373930701394845

Cleland JL, Duenas ET, Park A et al (2001) Development of poly(D, L-lactide-coglycolide) microsphere formulations containing recombinant human vascular endothelial growth factor to promote local angiogenesis. J Control Release 72:13-24

Cordeiro P, Temtem M, Winters C (2013) Spray congealing: applications in the pharmaceutical industry. Chem Today 31:69-72

Costantino HR, Johnson OL, Zale SE (2004) Relationship between encapsulated drug particle size and initial release of recombinant human growth hormone from biodegradable microspheres. J Pharm Sci 93:2624-2634. https://doi.org/10.1002/ jps. 20078

Cricchio V, Best M, Reverchon E et al (2017) Novel superparamagnetic microdevices based on magnetized PLGA/PLA microparticles obtained by supercritical fluid emulsion and coating by carboxybetaine-functionalized chitosan allowing the tuneable release of therapeutics. JPharmSci 106:2097-2105. https://doi. org/10.1016/j.xphs.2017.05.005

Crowley MM, Zhang F, Repka MA et al (2007) Pharmaceutical applications of hot-melt extrusion: part I. Drug Dev Ind Pharm 33:909-926. https://doi.org/10.1080/03639040701498759

D’Souza S, Faraj JA, Giovagnoli S, DeLuca PP (2013) Preparation, characterization, and in vivo evaluation of olanzapine poly(D, L-lactide-co-glycolide) microspheres. J Pharm (Cairo) 2013:831381. https://doi.org/10.1155/2013/831381
D’Souza S, Faraj JA, Giovagnoli S, Deluca PP (2014a) Development of risperidone PLGA microspheres. J Drug Deliv 2014:620464. https://doi.org/10.1155/2014/620464

D’Souza S, Faraj JA, Giovagnoli S, DeLuca PP (2014b) In vitro-in vivo correlation from lactide-co-glycolide polymeric dosage forms. Prog Biomater 3:131-142. https://doi.org/10.1007/s4020 4-014-0029-4

D’Souza S, Faraj JA, Giovagnoli S, DeLuca PP (2014c) IVIVC from long acting olanzapine microspheres. Int J Biomater. https://doi. org/10.1155/2014/407065

D’Souza S, Faraj JA, Dorati R, DeLuca PP (2015) enhanced degradation of lactide-co-glycolide polymer with basic nucleophilic drugs. Adv Pharma 20:15. https://doi.org/10.1155/2015/154239

Das S, Tucker I, Stewart P (2015) Inhaled dry powder formulations for treating tuberculosis. Curr Drug Deliv 12:26-39

Della Porta G, Falco N, Reverchon E (2010) NSAID drugs release from injectable microspheres produced by supercritical fluid emulsion extraction. J Pharm Sci 99:1484-1499. https://doi.org/10.1002/ jps. 21920

Della Porta G, Falco N, Reverchon E (2011) Continuous supercritical emulsions extraction: a new technology for biopolymer microparticles production. Biotechnol Bioeng 108:676-686. https:// doi.org/10.1002/bit.22972

Della Porta G, Falco N, Giordano E, Reverchon E (2013) PLGA microspheres by supercritical emulsion extraction: a study on insulin release in myoblast culture. J Biomater Sci Polym Ed 24:18311847. https://doi.org/10.1080/09205063.2013.807457

Dhanda DS, Tyagi P, Mirvish SS, Kompella UB (2013) Supercritical fluid technology based large porous celecoxib-PLGA microparticles do not induce pulmonary fibrosis and sustain drug delivery and efficacy for several weeks following a single dose. J Control Release 168:239-250. https://doi.org/10.1016/j.jconr el.2013.03.027

Di Giorgio L, Mvundura M, Tumusiime J et al (2018) Costs of administering injectable contraceptives through health workers and selfinjection: evidence from Burkina Faso, Uganda, and Senegal. Contraception 98:389-395. https://doi.org/10.1016/j.contracept ion.2018.05.018

Ding D, Zhu Q (2018) Recent advances of PLGA micro/nanoparticles for the delivery of biomacromolecular therapeutics. Mater Sci Eng C Mater Biol Appl 92:1041-1060. https://doi.org/10.1016/j. msec.2017.12.036

Duncanson WJ, Lin T, Abate AR et al (2012) Microfluidic synthesis of advanced microparticles for encapsulation and controlled release. Lab Chip 12:2135-2145. https://doi.org/10.1039/C2LC21164E

Dutta S, Moses JA, Anandharamakrishnan C (2018) Modern frontiers and applications of spray-freeze-drying in design of food and biological supplements. J Food Process Eng 41:e12881. https:// doi.org/10.1111/jfpe.12881

Elvassore N, Bertucco A, Caliceti P (2001) Production of proteinloaded polymeric microcapsules by compressed $\mathrm{CO}_{2}$ in a mixed solvent. Ind Eng Chem Res 40:795-800. https://doi.org/10.1021/ ie0004904

EMA (2014) Guideline on the pharmacokinetic and clinical evaluation 4 of modified release dosage forms (EMA/CPMP/EWP/280/96 Corr1)

Enlow EM, Luft JC, Napier ME, DeSimone JM (2011) Potent engineered PLGA nanoparticles by virtue of exceptionally high chemotherapeutic loadings. Nano Lett 11:808-813. https://doi. org/10.1021/nl104117p

Falco N, Reverchon E, Della Porta G (2012) Continuous supercritical emulsions extraction: packed tower characterization and application to poly(lactic-co-glycolic acid) + insulin microspheres production. Ind Eng Chem Res 51:8616-8623. https://doi. org/10.1021/ie300482n 
Falk R, Randolph TW, Meyer JD et al (1997) Controlled release of ionic compounds from poly (L-lactide) microspheres produced by precipitation with a compressed antisolvent. J Control Release 44:77-85. https://doi.org/10.1016/S0168-3659(96)01508-8

FDA (2013) FDA guidance for industry: technical considerations for pen, jet, and related injectors intended for use with drugs and biological products - ECA Academy

FDA (2018a) Two new intra-articular injections for knee osteoarthritis. Med Lett Drugs Ther 60:142-144

FDA (2018b) Triptorelin (Triptodur) for central precocious puberty. Med Lett Drugs Ther 60:7-8

Fu H, Wen X-G, Wang Z-H et al (2012) Risperidone-loaded longacting injectable microspheres prepared by ultra-fine particle processing system. Chin J New Drugs 21:795-799

Garner J, Skidmore S, Park H et al (2018) Beyond Q1/Q2: the impact of manufacturing conditions and test methods on drug release from PLGA-based microparticle depot formulations. J Pharm Sci 107:353-361. https://doi.org/10.1016/j.xphs.2017.10.027

Gasparini G, Kosvintsev SR, Stillwell MT, Holdich RG (2008) Preparation and characterization of PLGA particles for subcutaneous controlled drug release by membrane emulsification. Colloids Surf B Biointerfaces 61:199-207. https://doi.org/10.1016/j.colsu $\mathrm{rfb} .2007 .08 .011$

Gavini E, Chetoni P, Cossu M et al (2004) PLGA microspheres for the ocular delivery of a peptide drug, vancomycin using emulsification/spray-drying as the preparation method: in vitro/in vivo studies. Eur J Pharm Biopharm 57:207-212. https://doi. org/10.1016/j.ejpb.2003.10.018

Ghaderi R, Artursson P, Carlfors J (2000) A new method for preparing biodegradable microparticles and entrapment of hydrocortisone in DL-PLG microparticles using supercritical fluids. Eur J Pharm Sci 10:1-9

Giovagnoli S, Blasi P, Ricci M, Rossi C (2004) Biodegradable microspheres as carriers for native superoxide dismutase and catalase delivery. AAPS PharmSciTech 5:1-9. https://doi.org/10.1208/ pt050451

Giovagnoli S, Luca G, Casaburi I et al (2005) Long-term delivery of superoxide dismutase and catalase entrapped in poly(lactideco-glycolide) microspheres: in vitro effects on isolated neonatal porcine pancreatic cell clusters. J Control Release 107:65-77. https://doi.org/10.1016/j.jconrel.2005.05.021

Giovagnoli S, Blasi P, Schoubben A et al (2007) Preparation of large porous biodegradable microspheres by using a simple doubleemulsion method for capreomycin sulfate pulmonary delivery. Int J Pharm 333:103-111. https://doi.org/10.1016/j.ijpha rm.2006.10.005

Giovagnoli S, Blasi P, Ricci M et al (2008) Physicochemical characterization and release mechanism of a novel prednisone biodegradable microsphere formulation. J Pharm Sci 97:303-317. https:// doi.org/10.1002/jps. 21073

Giovagnoli S, Blasi P, Luca G et al (2010) Bioactive long-term release from biodegradable microspheres preserves implanted ALGPLO-ALG microcapsules from in vivo response to purified alginate. Pharm Res 27:285-295. https://doi.org/10.1007/s1109 5-009-0017-x

Giovagnoli S, Palazzo F, Di Michele A et al (2014) The influence of feedstock and process variables on the encapsulation of drug suspensions by spray-drying in fast drying regime: the case of novel antitubercular drug-palladium complex containing polymeric microparticles. J Pharm Sci 103:1255-1268

Girotra P, Singh SK, Nagpal K (2013) Supercritical fluid technology: a promising approach in pharmaceutical research. Pharm Dev Technol 18:22-38. https://doi.org/10.3109/10837 450.2012.726998

Go DP, Harvie DJE, Tirtaatmadja N et al (2014) A simple, scalable process for the production of porous polymer microspheres by ink-jetting combined with thermally induced phase separation. Part Part Syst Charact 31:685-698. https://doi.org/10.1002/ ppsc. 201300298

González GP, Moscoso NS, Lago FP (2018) A review of clinical and economic evaluations applied to psychotropic therapies used in the treatment of schizophrenia in Argentina. Pharmacoecon Open 2:233-239. https://doi.org/10.1007/s41669-017-0058-8

Greystone Research Associates (2018) A comprehensive report sustained release injectables to 2024. Greystone Research Associates, Amherst, $\mathrm{NH}$

Gu X, Li C, Yuan M et al (2018) Review on SPG membrane emulsification: an efficient approach to prepare uniform microspheric drug carrier. MOJ Drug Des Develop Ther 2:107-115

Guan J, Ferrell N, James Lee L, Hansford DJ (2006) Fabrication of polymeric microparticles for drug delivery by soft lithography. Biomaterials 27:4034-4041. https://doi.org/10.1016/j.biomateria 1s.2006.03.011

Guo W, Quan P, Fang L et al (2015) Sustained release donepezil loaded PLGA microspheres for injection: preparation, in vitro and in vivo study. Asian J Pharm Sci 10:405-414. https://doi. org/10.1016/j.ajps.2015.06.001

Guo L, Xiao X, Sun X, Qi C (2017a) Comparison of jet injector and insulin pen in controlling plasma glucose and insulin concentrations in type 2 diabetic patients. Medicine (Baltimore) 96:e5482. https://doi.org/10.1097/md.0000000000005482

Guo Y, Yang Y, He L et al (2017b) Injectable sustained-release depots of PLGA microspheres for insoluble drugs prepared by hot-melt extrusion. Pharm Res 34:2211-2222. https://doi.org/10.1007/ s11095-017-2228-x

Gupta V, Khan Y, Berkland CJ et al (2017) Microsphere-based scaffolds in regenerative engineering. Annu Rev Biomed Eng 19:135-161. https://doi.org/10.1146/annurev-bioeng-07151 6-044712

Han FY, Thurecht KJ, Whittaker AK, Smith MT (2016) Bioerodable PLGA-based microparticles for producing sustained-release drug formulations and strategies for improving drug loading. Front Pharmacol 7:185. https://doi.org/10.3389/fphar.2016.00185

Han FY, Whittaker AK, Howdle SM et al (2018) Formulation of bioerodible ketamine microparticles as an analgesic adjuvant treatment produced by supercritical fluid polymer encapsulation. Pharmaceutics 10:264. https://doi.org/10.3390/pharmaceutics10 040264

Hancocks RD, Spyropoulos F, Norton IT (2013) Comparisons between membranes for use in cross flow membrane emulsification. J Food Eng 116:382-389. https://doi.org/10.1016/j.jfood eng.2012.11.032

Hickey AJ, Misra A, Fourie PB (2016) Drug delivery systems for tuberculosis prevention and treatment. Wiley, New York

Ho TH, Dao TPT, Nguyen TA et al (2013) Cross-flow membrane emulsification technique for fabrication of drug-loaded particles. Adv Nat Sci Nanosci Nanotechnol 4:045008. https://doi. org/10.1088/2043-6262/4/4/045008

Hu M, Guo J, Yu Y et al (2017) Research advances of microencapsulation and its prospects in the petroleum industry. Materials (Basel). https://doi.org/10.3390/ma10040369

Huang X, Zhang Y, Yin G et al (2015) Tumor-targeted paclitaxelloaded folate conjugated poly(ethylene glycol)-poly(L-lactide) microparticles produced by supercritical fluid technology. J Mater Sci Mater Med 26:95. https://doi.org/10.1007/s1085 6-015-5447-x

Ibrahim M, Hatipoglu MK, Garcia-Contreras L (2018) SHetA2 dry powder aerosols for tuberculosis: formulation, design, and optimization using quality by design. Mol Pharm 15:300-313. https ://doi.org/10.1021/acs.molpharmaceut.7b01062

ICH Q1A (R2) (2003) Stability testing of new drug substances and products. In: European Medicines Agency - Commission. https 
://www.ema.europa.eu/en/ich-q1a-r2-stability-testing-new-drugsubstances-drug-products. Accessed $28 \mathrm{Feb} 2019$

Im H-Y, Sah H (2009) Ammonolysis-based microencapsulation technique using isopropyl formate as dispersed solvent. Int J Pharm 382:130-138. https://doi.org/10.1016/j.ijpharm.2009.08.020

Ishwarya SP, Anandharamakrishnan C, Stapley AGF (2015) Sprayfreeze-drying: a novel process for the drying of foods and bioproducts. Trends Food Sci Technol 41:161-181. https://doi. org/10.1016/j.tifs.2014.10.008

Jain RA (2000) The manufacturing techniques of various drug loaded biodegradable poly(lactide-co-glycolide) (PLGA) devices. Biomaterials 21:2475-2490. https://doi.org/10.1016/S0142 -9612(00)00115-0

Jain RA, Rhodes CT, Railkar AM et al (2000) Comparison of various injectable protein-loaded biodegradable poly(lactide-co-glycolide) (PLGA) devices: in situ-formed implant versus in situformed microspheres versus isolated microspheres. Pharm Dev Technol 5:201-207. https://doi.org/10.1081/PDT-100100535

Johnson OL, Jaworowicz W, Cleland JL et al (1997) The stabilization and encapsulation of human growth hormone into biodegradable microspheres. Pharm Res 14:730-735

Kale TR, Momin M (2014) Needle free injection technology—an overview. Innov Pharm 5:148

Kang Y, Wu J, Yin G et al (2008a) Preparation, characterization and in vitro cytotoxicity of indomethacin-loaded PLLA/ PLGA microparticles using supercritical $\mathrm{CO}_{2}$ technique. Eur J Pharm Biopharm 70:85-97. https://doi.org/10.1016/j. ejpb.2008.03.011

Kang Y, Yin G, Ouyang P et al (2008b) Preparation of PLLA/PLGA microparticles using solution enhanced dispersion by supercritical fluids (SEDS). J Colloid Interface Sci 322:87-94. https://doi. org/10.1016/j.jcis.2008.02.031

Kang Y-Q, Zhao C, Chen A-Z et al (2013) Study of lysozyme-loaded poly-L-lactide (PLLA) porous microparticles in a compressed $\mathrm{CO}_{2}$ antisolvent process. Materials (Basel) 6:3571-3583. https ://doi.org/10.3390/ma6083571

Kankala RK, Zhang YS, Wang S-B et al (2017) Supercritical fluid technology: an emphasis on drug delivery and related biomedical applications. Adv Healthc Mater. https://doi.org/10.1002/ adhm.201700433

Kanojia G, Have RT, Soema PC et al (2017) Developments in the formulation and delivery of spray dried vaccines. Hum Vaccin Immunother 13:2364-2378. https://doi.org/10.1080/21645 515.2017.1356952

Kapoor DN, Bhatia A, Kaur R et al (2015) PLGA: a unique polymer for drug delivery. Ther Deliv 6:41-58. https://doi.org/10.4155/ tde. 14.91

Kaufman MB (2017) Pharmaceutical approval update. P T 42:733-755

Keohane K, Brennan D, Galvin P, Griffin BT (2014) Silicon microfluidic flow focusing devices for the production of size-controlled PLGA based drug loaded microparticles. Int J Pharm 467:60-69. https://doi.org/10.1016/j.ijpharm.2014.03.051

Kim J-H, Paxton TE, Tomasko DL (1996) Microencapsulation of naproxen using rapid expansion of supercritical solutions. Biotechnol Prog 12:650-661. https://doi.org/10.1021/bp9600492

Kim J, Hong D, Chung Y, Sah H (2007) Ammonolysis-induced solvent removal: a facile approach for solidifying emulsion droplets into PLGA microspheres. Biomacromol 8:3900-3907. https:// doi.org/10.1021/bm700870x

Kluge J, Fusaro F, Casas N et al (2009a) Production of PLGA microand nanocomposites by supercritical fluid extraction of emulsions: I. Encapsulation of lysozyme. J Supercrit Fluids 50:327335. https://doi.org/10.1016/j.supflu.2009.05.010

Kluge J, Fusaro F, Mazzotti M, Muhrer G (2009b) Production of PLGA micro- and nanocomposites by supercritical fluid extraction of emulsions: II. Encapsulation of ketoprofen. J Supercrit Fluids 50:336-343. https://doi.org/10.1016/j.supflu.2009.05.002

Kondo K, Niwa T, Danjo K (2014) Preparation of sustained-release coated particles by novel microencapsulation method using three-fluid nozzle spray drying technique. Eur J Pharm Sci 51:11-19. https://doi.org/10.1016/j.ejps.2013.09.001

Koushik K, Kompella UB (2004) Preparation of large porous deslorelin-PLGA microparticles with reduced residual solvent and cellular uptake using a supercritical carbon dioxide process. Pharm Res 21:524-535. https://doi.org/10.1023/B:PHAM.0000019308 $.25479 . \mathrm{a} 4$

Koushik K, Dhanda DS, Cheruvu NPS, Kompella UB (2004) Pulmonary delivery of deslorelin: large-porous PLGA particles and HPbetaCD complexes. Pharm Res 21:1119-1126

Lang B, McGinity JW, Williams RO (2014) Hot-melt extrusion-basic principles and pharmaceutical applications. Drug Dev Ind Pharm 40:1133-1155. https://doi.org/10.3109/03639045.2013.838577

Leblanc D (2018) PLGA microspheres: the art of the science. Pharmaceutical Manufacturing

Lee S, Kim MS, Kim JS et al (2006) Controlled delivery of a hydrophilic drug from a biodegradable microsphere system by supercritical anti-solvent precipitation technique. J Microencapsul 23:741-749. https://doi.org/10.1080/09687860600945552

Lee Y-H, Mei F, Bai M-Y et al (2010) Release profile characteristics of biodegradable-polymer-coated drug particles fabricated by dualcapillary electrospray. J Control Release 145:58-65. https://doi. org/10.1016/j.jconrel.2010.03.014

Lee BK, Yun YH, Choi JS et al (2012) Fabrication of drug-loaded polymer microparticles with arbitrary geometries using a piezoelectric inkjet printing system. Int J Pharm 427:305-310. https ://doi.org/10.1016/j.ijpharm.2012.02.011

Lee M, Kang J, Sah H (2013) Utilization of catalytic hydrolysis of ethyl acetate for solvent removal during microencapsulation. J Microencapsul 30:346-355. https://doi.org/10.3109/02652 048.2012.735262

Lee BK, Yun Y, Park K (2016) PLA micro- and nano-particles. Adv Drug Deliv Rev 107:176-191. https://doi.org/10.1016/j. addr.2016.05.020

Li W, Dong H, Tang G et al (2015) Controllable microfluidic fabrication of Janus and microcapsule particles for drug delivery applications. RSC Adv 5:23181-23188. https://doi.org/10.1039/ C4RA17153E

Liang Z, Ni R, Zhou J, Mao S (2015) Recent advances in controlled pulmonary drug delivery. Drug Discov Today 20:380-389. https ://doi.org/10.1016/j.drudis.2014.09.020

Liang Y-J, Yu H, Feng G et al (2017) High-performance poly(lactic-coglycolic acid)-magnetic microspheres prepared by rotating membrane emulsification for transcatheter arterial embolization and magnetic ablation in VX2 liver tumors. ACS Appl Mater Interfaces 9:43478-43489. https://doi.org/10.1021/acsami.7b14330

Liu R, Ma G, Meng F-T, Su Z-G (2005a) Preparation of uniform-sized PLA microcapsules by combining Shirasu porous glass membrane emulsification technique and multiple emulsion-solvent evaporation method. J Control Release 103:31-43. https://doi. org/10.1016/j.jconrel.2004.11.025

Liu R, Ma G-H, Wan Y-H, Su Z-G (2005b) Influence of process parameters on the size distribution of PLA microcapsules prepared by combining membrane emulsification technique and double emulsion-solvent evaporation method. Colloids Surf B Biointerfaces 45:144-153. https://doi.org/10.1016/j.colsurfb.2005.08.004

Liu R, Huang S-S, Wan Y-H et al (2006) Preparation of insulin-loaded PLA/PLGA microcapsules by a novel membrane emulsification method and its release in vitro. Colloids Surf B Biointerfaces 51:30-38. https://doi.org/10.1016/j.colsurfb.2006.05.014

Liu W, Yang X-L, Ho WSW (2011) Preparation of uniform-sized multiple emulsions and micro/nano particulates for drug delivery by 
membrane emulsification. J Pharm Sci 100:75-93. https://doi. org/10.1002/jps.22272

Liu W, Chen XD, Selomulya C (2015) On the spray drying of uniform functional microparticles. Particuology 22:1-12. https://doi. org/10.1016/j.partic.2015.04.001

Lloyd DM, Norton IT, Spyropoulos F (2014) Processing effects during rotating membrane emulsification. J Membr Sci 466:8-17. https ://doi.org/10.1016/j.memsci.2014.04.035

Lu Y, Park K (2012) Microencapsulation: methods and pharmaceutical applications. In: Encyclopedia of pharmaceutical science and technology, 4th edn. Informa Healthcare, USA

Lu J, Yin A, Zhang M et al (2017) Optimization and evaluation of monodispersed tetrandrine-loaded PLA microspheres prepared with a SPG membrane emulsification technique. SOJ Pharm Pharm Sci 4:1-11. https://doi.org/10.15226 /2374-6866/4/3/00148

Luan X, Bodmeier R (2006) In situ forming microparticle system for controlled delivery of leuprolide acetate: influence of the formulation and processing parameters. Eur J Pharm Sci 27:143-149. https://doi.org/10.1016/j.ejps.2005.09.002

Ma G (2014) Microencapsulation of protein drugs for drug delivery: strategy, preparation, and applications. J Control Release 193:324-340. https://doi.org/10.1016/j.jconrel.2014.09.003

Makadia HK, Siegel SJ (2011) Poly lactic-co-glycolic acid (PLGA) as biodegradable controlled drug delivery carrier. Polymers (Basel) 3:1377-1397. https://doi.org/10.3390/polym3031377

Mao S, Xu J, Cai C et al (2007) Effect of WOW process parameters on morphology and burst release of FITC-dextran loaded PLGA microspheres. Int J Pharm 334:137-148. https://doi. org/10.1016/j.ijpharm.2006.10.036

Martín-Banderas L, Flores-Mosquera M, Riesco-Chueca P et al (2005) Flow focusing: a versatile technology to produce size-controlled and specific-morphology microparticles. Small 1:688-692. https ://doi.org/10.1002/smll.200500087

Miranda MS, Rodrigues MT, Domingues RMA et al (2018) Exploring inhalable polymeric dry powders for anti-tuberculosis drug delivery. Mater Sci Eng C Mater Biol Appl 93:1090-1103. https ://doi.org/10.1016/j.msec.2018.09.004

Mishima K, Matsuyama K, Tanabe D et al (2000) Microencapsulation of proteins by rapid expansion of supercritical solution with a nonsolvent. AIChE J 46:857-865. https://doi.org/10.1002/ aic.690460418

Mu L, Feng SS (2001) Fabrication, characterization and in vitro release of paclitaxel (Taxol) loaded poly (lactic-co-glycolic acid) microspheres prepared by spray drying technique with lipid/cholesterol emulsifiers. J Control Release 76:239-254

Mueller M, Reichardt W, Koerner J, Groettrup M (2012) Coencapsulation of tumor lysate and CpG-ODN in PLGA-microspheres enables successful immunotherapy of prostate carcinoma in TRAMP mice. J Control Release 162:159-166. https://doi.org/10.1016/j. jconrel.2012.06.015

Mundargi RC, Rangaswamy V, Aminabhavi TM (2011) Spray drying technique to produce controlled release formulations of zidovudine-an anti-HIV drug. J Appl Polym Sci 122:2244-2251. https ://doi.org/10.1002/app.31592

Mutsatsa S (2017) The use of long-acting injectable antipsychotic medication. British Journal of Mental Health Nursing 6:114-117. https://doi.org/10.12968/bjmh.2017.6.3.114

Nagavarma BVN, Yadav HKS, Ayaz A et al (2012) Different techniques for preparation of polymeric nanoparticles-A. Asian J Pharm Clin Res 5:16-23

New FDA Approved Drugs for 2019 | CenterWatch. https://www.cente rwatch.com/drug-information/fda-approved-drugs/. Accessed 26 Feb 2019

Nikolić N, Page N, Akram A, Khan M (2017) The impact of paliperidone palmitate long-acting injection on hospital admissions in a mental health setting. Int Clin Psychopharmacol 32:95-102. https://doi.org/10.1097/YIC.0000000000000155

Nykamp G, Carstensen U, Müller BW (2002) Jet milling-a new technique for microparticle preparation. Int J Pharm 242:79-86

O'Connor G, Krishnan N, Fagan-Murphy A et al (2019) Inhalable poly(lactic-co-glycolic acid) (PLGA) microparticles encapsulating all-trans-retinoic acid (ATRA) as a host-directed, adjunctive treatment for mycobacterium tuberculosis infection. Eur J Pharm Biopharm 134:153-165. https://doi.org/10.1016/j. ejpb.2018.10.020

Oliveira MB, Mano JF (2011) Polymer-based microparticles in tissue engineering and regenerative medicine. Biotechnol Prog 27:897-912. https://doi.org/10.1002/btpr.618

Orbis biosciences precision particle fabrication technology. In: Orbis biosciences. https://orbisbio.com/. Accessed 15 Feb 2019

Palazzo F, Giovagnoli S, Schoubben A et al (2013) Development of a spray-drying method for the formulation of respirable microparticles containing ofloxacin-palladium complex. Int J Pharm 440:273-282. https://doi.org/10.1016/j.ijpharm.2012.05.045

Palmer D, Bamsey K, Groves R et al (2017) Printing particles: a highthroughput technique for the production of uniform, bioresorbable polymer microparticles and encapsulation of therapeutic peptides. Chem Eng Sci 166:122-129. https://doi.org/10.1016/j. ces.2017.03.038

Panzitta M, Bruno G, Giovagnoli S et al (2015) Drug delivery system innovation and health technology assessment: upgrading from clinical to technological assessment. Int J Pharm 495:1005-1018. https://doi.org/10.1016/j.ijpharm.2015.09.026

Patel R, Chesney E, Taylor M et al (2018) Is paliperidone palmitate more effective than other long-acting injectable antipsychotics? Psychol Med 48:1616-1623. https://doi.org/10.1017/S0033 291717003051

Patomchaiviwat V, Paeratakul O, Kulvanich P (2008) Formation of inhalable rifampicin-poly(L-lactide) microparticles by supercritical anti-solvent process. AAPS PharmSciTech 9:1119-1129. https://doi.org/10.1208/s12249-008-9152-7

Peng X, Ascher-Svanum H, Faries D et al (2011) Decline in hospitalization risk and health care cost after initiation of depot antipsychotics in the treatment of schizophrenia. Clinicoecon Outcomes Res 3:9-14. https://doi.org/10.2147/CEOR.S16061

Perez A, Hernández R, Velasco D et al (2015) Poly (lactic-co-glycolic acid) particles prepared by microfluidics and conventional methods. Modulated particle size and rheology. J Colloid Interface Sci 441:90-97. https://doi.org/10.1016/j.jcis.2014.10.049

Perry JL, Herlihy KP, Napier ME, DeSimone JM (2011) PRINT: a novel platform toward shape and size specific nanoparticle theranostics. Acc Chem Res 44:990-998. https://doi.org/10.1021/ ar2000315

Piacentini E, Drioli E, Giorno L (2014) Membrane emulsification technology: twenty-five years of inventions and research through patent survey. J Membr Sci 468:410-422. https://doi.org/10.1016/j. memsci.2014.05.059

Piacentini E, Dragosavac M, Giorno L (2017) Pharmaceutical particles design by membrane emulsification: preparation methods and applications in drug delivery. Curr Pharm Des 23:302-318. https ://doi.org/10.2174/1381612823666161117160940

Puccetti M, Giovagnoli S, Zelante T et al (2018) Development of novel indole-3-aldehyde-loaded gastro-resistant spray-dried microparticles for postbiotic small intestine local delivery. J Pharm Sci 107:2341-2353. https://doi.org/10.1016/j.xphs.2018.04.023

Qi F, Wu J, Yang T et al (2014) Mechanistic studies for monodisperse exenatide-loaded PLGA microspheres prepared by different methods based on SPG membrane emulsification. Acta Biomater 10:4247-4256. https://doi.org/10.1016/j.actbio.2014.06.018

Qi F, Wu J, Li H, Ma G (2018) Recent research and development of PLGA/PLA microspheres/nanoparticles: a review in 
scientific and industrial aspects. Front Chem Sci Eng. https:// doi.org/10.1007/s11705-018-1729-4

Ramazani F, Chen W, van Nostrum CF et al (2016) Strategies for encapsulation of small hydrophilic and amphiphilic drugs in PLGA microspheres: state-of-the-art and challenges. Int J Pharm 499:358-367. https://doi.org/10.1016/j.jpharm.2016.01.020

Ravasio R, Nicolò G, Vaggi M (2015) Cost-effectiveness analysis of paliperidone palmitate versus long-acting risperidone as maintenance treatment in schizophrenia patients in Italy. Global Reg Health Technol Assess. https://doi.org/10.5301/grhta.5000186

Rawat A, Stippler E, Shah VP, Burgess DJ (2011) Validation of USP apparatus 4 method for microsphere in vitro release testing using risperdal consta. Int J Pharm 420:198-205. https://doi. org/10.1016/j.ijpharm.2011.08.035

Ricci M, Blasi P, Giovagnoli S et al (2005) Ketoprofen controlled release from composite microcapsules for cell encapsulation: effect on post-transplant acute inflammation. J Control Release 107:395-407. https://doi.org/10.1016/j.jconrel.2005.06.023

Rivera PA, Martinez-Oharriz MC, Rubio M et al (2004) Fluconazole encapsulation in PLGA microspheres by spray-drying. J Microencapsul 21:203-211. https://doi.org/10.1080/026520403100016 37811

Rosca ID, Watari F, Uo M (2004) Microparticle formation and its mechanism in single and double emulsion solvent evaporation. J Control Release 99:271-280. https://doi.org/10.1016/j.jconr el.2004.07.007

Royals MA, Fujita SM, Yewey GL et al (1999) Biocompatibility of a biodegradable in situ forming implant system in rhesus monkeys. J Biomed Mater Res 45:231-239

Salvacyl $^{\circledR}$, Moapar ${ }^{\circledR}$. In: Debiopharm Group. https://www.debiopharm .com/debiopharm-international/products/salvacylmoapar/. Accessed 26 Feb 2019

Sastre RL, Olmo R, Teijón C et al (2007) 5-Fluorouracil plasma levels and biodegradation of subcutaneously injected drug-loaded microspheres prepared by spray-drying poly(D, L-lactide) and poly(D, L-lactide-co-glycolide) polymers. Int J Pharm 338:180190. https://doi.org/10.1016/j.ijpharm.2007.02.001

Schoubben A, Blasi P, Giovagnoli S et al (2009) Novel composite microparticles for protein stabilization and delivery. Eur J Pharm Sci 36:226-234. https://doi.org/10.1016/j.ejps.2008.09.008

Schoubben A, Blasi P, Giovagnoli S et al (2010) Simple and scalable method for peptide inhalable powder production. Eur J Pharm Sci 39:53-58. https://doi.org/10.1016/j.ejps.2009.10.010

Schoubben A, Blasi P, Deluca PP (2012) Effect of agitation regimen on the in vitro release of leuprolide from poly(lactic-co-glycolic) acid microparticles. J Pharm Sci 101:1212-1220. https://doi. org/10.1002/jps.23029

Schoubben A, Cavicchi A, Barberini L et al (2015) Dynamic behavior of a spring-powered micronozzle needle-free injector. Int $\mathrm{J}$ Pharm 491:91-98. https://doi.org/10.1016/j.ijpharm.2015.05.067

Selmin F, Blasi P, DeLuca PP (2012) Accelerated polymer biodegradation of risperidone poly(D, L-lactide-co-glycolide) microspheres. AAPS PharmSciTech 13:1465-1472. https://doi.org/10.1208/ s12249-012-9874-4

Shaver MP, Cameron DJA (2010) Tacticity control in the synthesis of poly(lactic acid) polymer stars with dipentaerythritol cores. Biomacromol 11:3673-3679. https://doi.org/10.1021/bm101140d

Silva PS, Starov VM, Holdich RG (2017) Membrane emulsification: formation of water in oil emulsions using a hydrophilic membrane. Colloids Surf A 532:297-304. https://doi.org/10.1016/j. colsurfa.2017.04.077

Silverman BL, Blethen SL, Reiter EO et al (2002) A long-acting human growth hormone (Nutropin Depot): efficacy and safety following two years of treatment in children with growth hormone deficiency. J Pediatr Endocrinol Metab 15(Suppl 2):715-722
Soh SH, Lee LY (2019) Microencapsulation and nanoencapsulation using supercritical fluid (SCF) techniques. Pharmaceutics 11:21. https://doi.org/10.3390/pharmaceutics11010021

Sosnik A, Seremeta KP (2015) Advantages and challenges of the spray-drying technology for the production of pure drug particles and drug-loaded polymeric carriers. Adv Colloid Interface Sci 223:40-54. https://doi.org/10.1016/j.cis.2015.05.003

Swider E, Koshkina O, Tel J et al (2018) Customizing poly(lactic-coglycolic acid) particles for biomedical applications. Acta Biomater 73:38-51. https://doi.org/10.1016/j.actbio.2018.04.006

Tabernero A, Martín del Valle EM, Galán MA (2012) Supercritical fluids for pharmaceutical particle engineering: methods, basic fundamentals and modelling. Chem Eng Process 60:9-25. https ://doi.org/10.1016/j.cep.2012.06.004

Tavares M, Cabral RP, Costa C et al (2017) Development of PLGA dry powder microparticles by supercritical $\mathrm{CO}_{2}$-assisted spray-drying for potential vaccine delivery to the lungs. J Supercrit Fluids 128:235-243. https://doi.org/10.1016/j.supflu.2017.06.004

Thomasin C, Merkle HP, Gander B (1998) Drug microencapsulation by PLA/PLGA coacervation in the light of thermodynamics. 2 . Parameters determining microsphere formation. J Pharm Sci 87:269-275. https://doi.org/10.1021/js970048j

Tice T (2017) A 30-year history of PLG applications in parenteral controlled drug release. Pharm Technol 41:26-32

Tomic I, Vidis-Millward A, Mueller-Zsigmondy M, Cardot J-M (2016) Setting accelerated dissolution test for PLGA microspheres containing peptide, investigation of critical parameters affecting drug release rate and mechanism. Int J Pharm 505:42-51. https://doi. org/10.1016/j.ijpharm.2016.03.048

Tracy MA (1998) Development and scale-up of a microsphere protein delivery system. Biotechnol Prog 14:108-115. https://doi. org/10.1021/bp9701271

Tran M-K, Hassani LN, Calvignac B et al (2013) Lysozyme encapsulation within PLGA and $\mathrm{CaCO}_{3}$ microparticles using supercritical $\mathrm{CO}_{2}$ medium. J Supercrit Fluids 79:159-169. https://doi. org/10.1016/j.supflu.2013.02.024

Tu LS, Dehghani F, Foster NR (2002) Micronisation and microencapsulation of pharmaceuticals using a carbon dioxide antisolvent. Powder Technol 126:134-149. https://doi.org/10.1016/S0032 $-5910(02) 00045-1$

Ungaro F, d'Angelo I, Miro A et al (2012) Engineered PLGA nanoand micro-carriers for pulmonary delivery: challenges and promises. J Pharm Pharmacol 64:1217-1235. https://doi.org/10.111 1/j.2042-7158.2012.01486.x

van de Weert M, Hoechstetter J, Hennink WE, Crommelin DJ (2000) The effect of a water/organic solvent interface on the structural stability of lysozyme. J Control Release 68:351-359

Vladisavljević GT (2015) Structured microparticles with tailored properties produced by membrane emulsification. Adv Coll Interface Sci 225:53-87. https://doi.org/10.1016/j.cis.2015.07.013

Vladisavljević GT, Duncanson WJ, Shum HC, Weitz DA (2012) Emulsion templating of poly(lactic acid) particles: droplet formation behavior. Langmuir 28:12948-12954. https://doi.org/10.1021/ la302092f

Vladisavljević GT, Khalid N, Neves MA et al (2013) Industrial labon-a-chip: design, applications and scale-up for drug discovery and delivery. Adv Drug Deliv Rev 65:1626-1663. https://doi. org/10.1016/j.addr.2013.07.017

Vladisavljević GT, Kobayashi I, Nakajima M (2016) Membrane emulsification principles. In: Drioli E, Giorno L (eds) Encyclopedia of membranes. Springer, Berlin, pp 1228-1231

Vo CL-N, Park C, Lee B-J (2013) Current trends and future perspectives of solid dispersions containing poorly water-soluble drugs. Eur J Pharm Biopharm 85:799-813. https://doi.org/10.1016/j. ejpb.2013.09.007 
Wagenaar BW, Müller BW (1994) Piroxicam release from spray-dried biodegradable microspheres. Biomaterials 15:49-54

Wan F, Yang M (2016) Design of PLGA-based depot delivery systems for biopharmaceuticals prepared by spray drying. Int J Pharm 498:82-95. https://doi.org/10.1016/j.ijpharm.2015.12.025

Wan F, Maltesen MJ, Andersen SK et al (2014) One-step production of protein-loaded PLGA microparticles via spray drying using 3-fluid nozzle. Pharm Res 31:1967-1977. https://doi. org/10.1007/s11095-014-1299-1

Wang Y, Kho K, Cheow WS, Hadinoto K (2012) A comparison between spray drying and spray freeze drying for dry powder inhaler formulation of drug-loaded lipid-polymer hybrid nanoparticles. Int J Pharm 424:98-106. https://doi.org/10.1016/j.ijpha rm.2011.12.045

Wang Y, Qu W, Choi SH (2016) FDA's regulatory science program for generic PLA/PLGA-based drug products. Am Pharm Rev. https ://doi.org/10.3390/ijms20010204

Wanning S, Süverkrüp R, Lamprecht A (2015) Pharmaceutical spray freeze drying. Int J Pharm 488:136-153. https://doi. org/10.1016/j.ijpharm.2015.04.053

Werly EF, Bauman EK (1964) Production of submicronic powder by spray-freezing. Arch Environ Health 9:567-571

Wichert B, Rohdewald P (1990) A new method for the preparation of drug containing polylactic acid microparticles without using organic solvents. J Control Release 14:269-283. https://doi. org/10.1016/0168-3659(90)90167-R

Wischke C, Schwendeman SP (2008) Principles of encapsulating hydrophobic drugs in PLA/PLGA microparticles. Int J Pharm 364:298-327. https://doi.org/10.1016/j.ijpharm.2008.04.042

Xie J, Wang C-H (2007) Encapsulation of proteins in biodegradable polymeric microparticles using electrospray in the Taylor cone-jet mode. Biotechnol Bioeng 97:1278-1290. https://doi. org/10.1002/bit.21334

Xie J, Ng WJ, Lee LY, Wang C-H (2008) Encapsulation of protein drugs in biodegradable microparticles by co-axial electrospray. J Colloid Interface Sci 317:469-476. https://doi.org/10.1016/j. jcis.2007.09.082

Xie J, Rezvanpour A, Wang C-H, Hua J (2010) Electric field controlled electrospray deposition for precise particle pattern and cell pattern formation. AIChE J 56:2607-2621. https://doi.org/10.1002/ aic. 12198

Xu Q, Hashimoto M, Dang TT et al (2009) Preparation of monodisperse biodegradable polymer microparticles using a microfluidic flow-focusing device for controlled drug delivery. Small 5:15751581. https://doi.org/10.1002/smll.200801855

Yamaguchi Y, Takenaga M, Kitagawa A et al (2002) Insulin-loaded biodegradable PLGA microcapsules: initial burst release controlled by hydrophilic additives. J Control Release 81:235-249

Yandrapu SK, Upadhyay AK, Petrash JM, Kompella UB (2013) Nanoparticles in porous microparticles prepared by supercritical infusion and pressure quench technology for sustained delivery of bevacizumab. Mol Pharm 10:4676-4686. https://doi. org/10.1021/mp400487f

Yang L, Li M, Tao L et al (2009) Cost-effectiveness of long-acting risperidone injection versus alternative atypical antipsychotic agents in patients with schizophrenia in China. Value Health 12(Suppl 3):S66-69. https://doi.org/10.1111/j.1524-4733.2009.00630.x

Yaszemski MJ, Trantolo DJ, Lewandrowski K-U et al (2003) Tissue engineering and novel delivery systems. CRC Press, Boca Raton

Ye M, Kim S, Park K (2010) Issues in long-term protein delivery using biodegradable microparticles. J Control Release 146:241-260. https://doi.org/10.1016/j.jconrel.2010.05.011

Yeo Y, Baek N, Park K (2001) Microencapsulation methods for delivery of protein drugs. Biotechnol Bioprocess Eng 6:213-230. https://doi.org/10.1007/BF02931982

Youan B-BC (2004) Microencapsulation of superoxide dismutase into biodegradable microparticles by spray-drying. Drug Deliv 11:209-214. https://doi.org/10.1080/10717540490280363

Young TJ, Johnston KP, Mishima K, Tanaka H (1999) Encapsulation of lysozyme in a biodegradable polymer by precipitation with a vapor-over-liquid antisolvent. J Pharm Sci 88:640-650. https:// doi.org/10.1021/js980237h

Zhang Y-Z, Liao X-M, Yin G-F et al (2012) Preparation of water soluble drugs-loaded microparticles using modified solution enhanced dispersion by supercritical $\mathrm{CO}_{2}$. Powder Technol 221:343-350. https://doi.org/10.1016/j.powtec.2012.01.023

Zhang L, Si T, Fischer AJ et al (2015) Coaxial electrospray of ranibizumab-loaded microparticles for sustained release of anti-VEGF therapies. PLoS ONE 10:e0135608. https://doi.org/10.1371/ journal.pone. 0135608

Zhao R, Xu J, Guo B (2018) Preparation and in vitro evaluation of biodegradable microspheres with narrow size distribution for pulmonary delivery. Indian J Pharm Sci 79:930-938. https://doi. org/10.4172/pharmaceutical-sciences. 1000310

Zheng N, Sun D, Zou P, Jiang W (2017) Scientific and regulatory considerations for generic complex drug products containing nanomaterials. AAPS J 19:619-631

Zhou J, Hirota K, Ackermann R et al (2018) Reverse engineering the 1-month Lupron Depot ${ }^{\circledR}$. AAPS J 20:105. https://doi. org/10.1208/s12248-018-0253-2

Zhu C, Huang Y, Zhang X et al (2015) Comparative studies on exenatide-loaded poly (D, L-lactic-co-glycolic acid) microparticles prepared by a novel ultra-fine particle processing system and spray drying. Colloids Surf B Biointerfaces 132:103-110. https://doi. org/10.1016/j.colsurfb.2015.05.001

Ziaee A, Albadarin AB, Padrela L et al (2019) Spray drying of pharmaceuticals and biopharmaceuticals: critical parameters and experimental process optimization approaches. Eur J Pharm Sci 127:300-318. https://doi.org/10.1016/j.ejps.2018.10.026

Publisher's Note Springer Nature remains neutral with regard to jurisdictional claims in published maps and institutional affiliations. 